U. S. DEPARTMENT OF THE INTERIOR

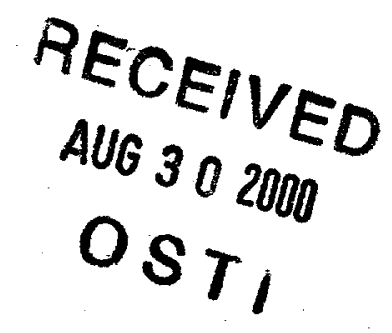

U. S. GEOLOGICAL SURVEY

\title{
Geologic map of the Oasis Valley basin and vicinity, Nye County, Nevada
}

Mapped and compiled by:

C. J. Fridrich', S. A. Minor', P. L. Ryder', and J. L. Slate'

With contributions from:

R. G. Warren ${ }^{3}$, T. G. Hildenbrand ${ }^{2}$, D. A. Sawyer', and P. P. Orkild 1

Digital cartography by:

P. L. Ryder' and D. J. Grunwald ${ }^{1}$

1 USGS, Denver, CO

2 USGS, Menlo Park, CA

3 Los Alamos National Labs, Los Alamos, NM

Open-File Report 99-533-B

Prepared in cooperation with the U. S. Department of Energy

This report is preliminary and has not been reviewed for conformity with U. S. Geological Survey editorial standards (or with the North American Stratigraphic Code). Any use of trade, product, or firm names is for descriptive purposes and does not imply endorsement by the U. S. Geological Survey. 


\section{DISCLAIMER}

This report was prepared as an account of work sponsored by an agency of the United States Government. Neither the United States Government nor any agency thereof, nor any of their employees, make any warranty, express or implied, or assumes any legal liability or responsibility for the accuracy, completeness, or usefulness of any information, apparatus, product, or process disclosed, or represents that its use would not infringe privately owned rights. Reference herein to any specific commercial product, process, or service by trade name, trademark, manufacturer, or otherwise does not necessarily constitute or imply its endorsement, recommendation, or favoring by the United States Government or any agency thereof. The views and opinions of authors expressed herein do not necessarily state or reflect those of the United States Government or any agency thereof. 


\section{DISCLAIMER}

Portions of this document may be illegible in electronic image products. Images are produced from the best available original document. 
Introduction

This map and accompanying cross sections present an updated synthesis of the geologic framework of the Oasis Valley area, a major groundwater discharge site located about $15 \mathrm{~km}$ west of the Nevada Test Site (see Fig. 1). Most of the data presented in this compilation is new geologic map data, as discussed below. In addition, the cross sections incorporate new geophysical data that have become available in the last three years (Grauch and others, 1997; written comm., 1999; Hildenbrand and others, 1999; Mankinen and others, 1999). Geophysical data are used to estimate the thickness of the Tertiary volcanic and sedimentary rocks on the cross sections, and to identify major concealed structures (Fig. 1). Large contiguous parts of the map area are covered either by alluvium or by volcanic units deposited after development of the major structures present at the depth of the water table and below. Hence, geophysical data provide critical constraints on our geologic interpretations. A companion paper by Fridrich and others (1999) and the above-cited reports by Hildenbrand and others (1999) and Mankinen and others (1999) provide explanations of the interpretations that are presented graphically on this map.

This map covers nine 7.5-minute quadrangles in Nye County, Nevada, centered on the Thirsty Canyon SW quadrangle (Fig. 1), and is a compilation of one published quadrangle map (O'Connor and others, 1966) and eight new quadrangle maps, two of which have been previously released (Minor and others; 1997; 1998). The new bedrock mapping was completed by Minor from 1991 to 1995 , by Fridrich from 1992 to 1998 , and by Ryder from 1997 to 1998 . The new maps are partly revisions of unpublished reconnaissance maps by Orkild (six quadrangles, mapped in the 1960's) and of previously published maps of 3 quadrangles, by Maldonado and Hausback (1990), by Lipman and others (1966); and by Sargent and Orkild (1976). In addition, the distribution of the pre-Tertiary rocks of northern Bare Mountain was compiled from Monsen and others (1992) with only minor modification. The descriptions of the pre-Tertiary map units are condensed from the 


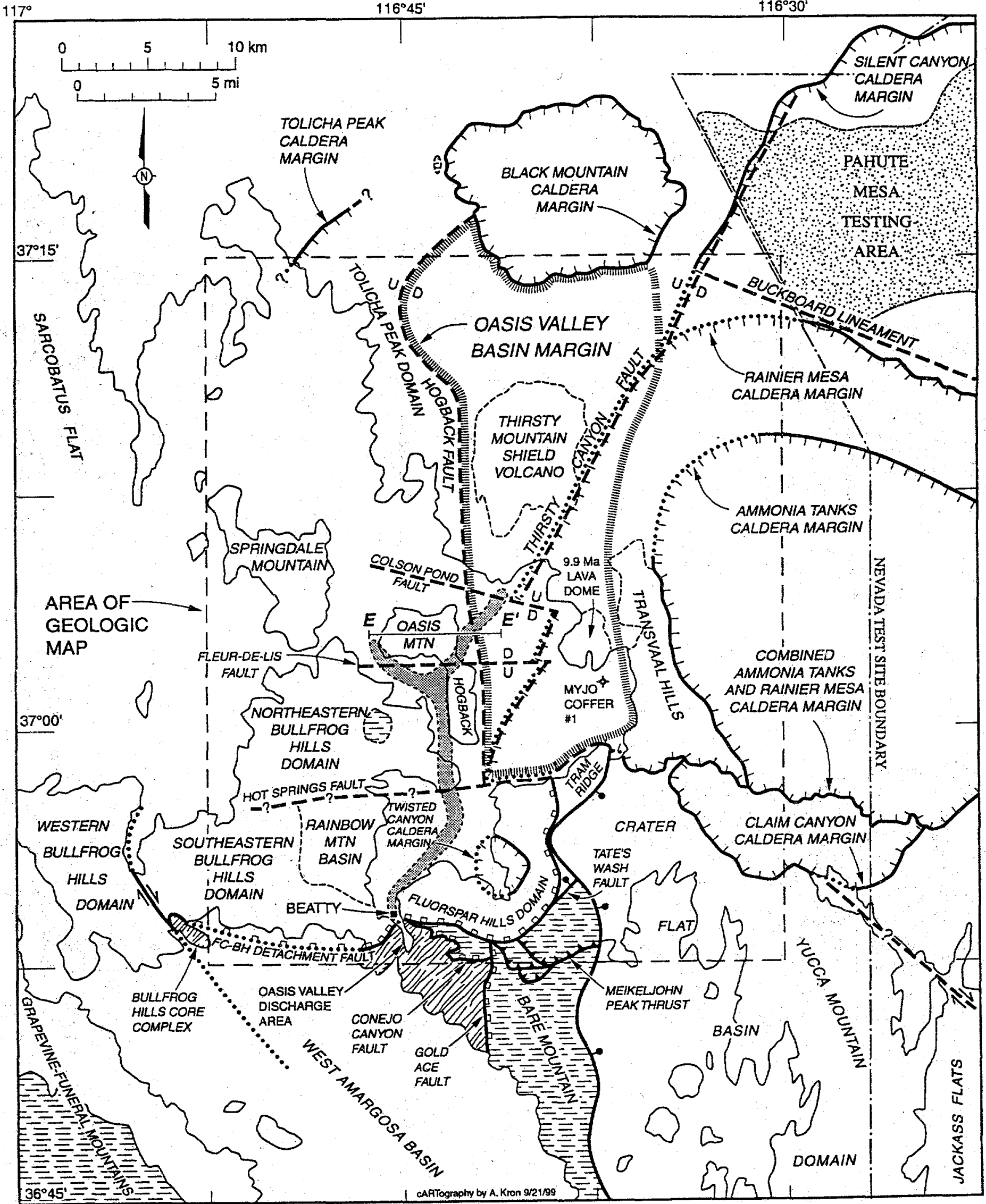

Figure 1. Caption, explanation of symbols, structural domain map, and index to quadrangles on next page. 


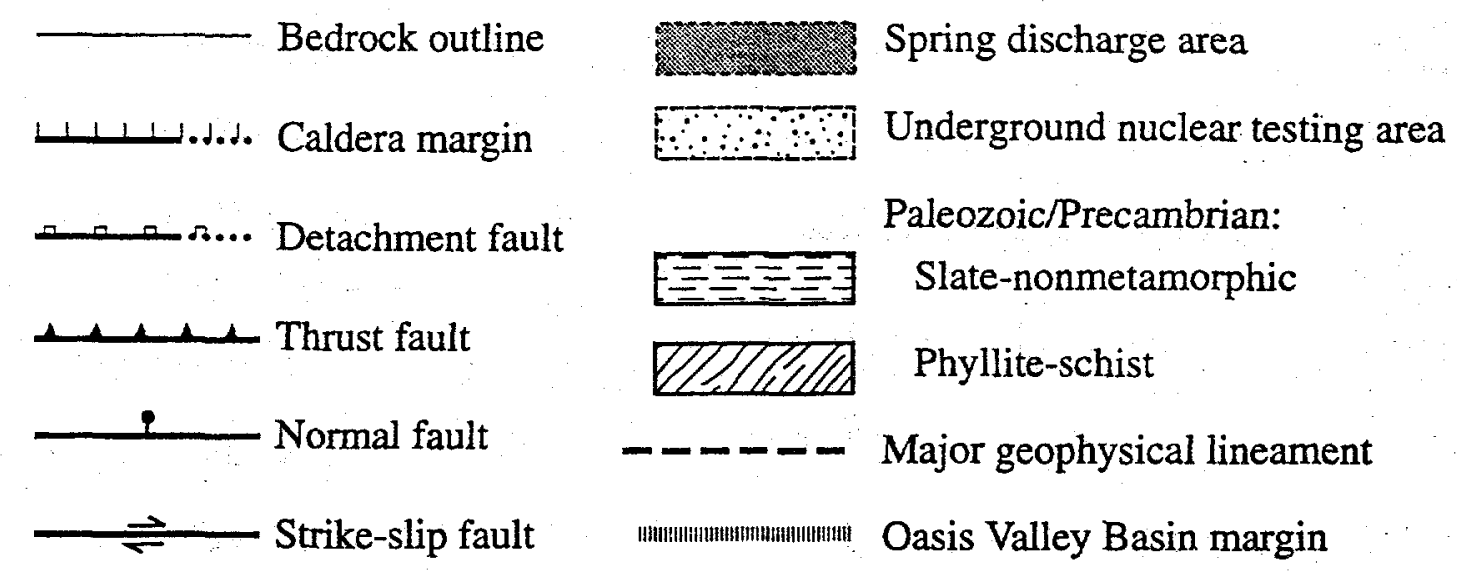

INDEX TO 7.5 MINUTE QUADRANGLES STRUCTURAL DOMAIN MAP

\begin{tabular}{|c|c|c|c|c|}
\hline $117^{\circ}$ & \multicolumn{2}{|c|}{$116^{\circ} 45^{\prime}$} & \multicolumn{2}{|c|}{$116^{\circ} 30^{\circ}$} \\
\hline $\begin{array}{l}\text { Tolicha } \\
\text { Peak } \\
\text { SW }\end{array}$ & $\begin{array}{l}\text { Tolicha } \\
\text { Peak }\end{array}$ & $\begin{array}{l}\text { Black } \\
\text { Min }\end{array}$ & $\begin{array}{l}\text { Trail } \\
\text { Ridge }\end{array}$ & $\begin{array}{l}\text { Silent } \\
\text { Butte }\end{array}$ \\
\hline $\begin{array}{c}\text { Springdale } \\
\text { NW }\end{array}$ & $\begin{array}{c}\text { Springdale } \\
\text { NE }\end{array}$ & $\begin{array}{c}\text { Thirsty } \\
\text { Canyon } \\
\text { NW }\end{array}$ & $\begin{array}{l}\text { Thirsty } \\
\text { Canyon }\end{array}$ & $\begin{array}{l}\text { Scrugham } \\
\text { Peak }\end{array}$ \\
\hline $\begin{array}{l}\text { Springdale } \\
\text { SW }\end{array}$ & Springdale & $\begin{array}{c}\text { Thirsty } \\
\text { Canyon } \\
\text { SW }\end{array}$ & $\begin{array}{c}\text { Thirsty } \\
\text { Canyon } \\
\text { SE }\end{array}$ & $\begin{array}{c}\text { Timber } \\
\text { Mtn }\end{array}$ \\
\hline $\begin{array}{c}\text { Bullfrog } \\
\text { Mtn }\end{array}$ & Beatty & $\begin{array}{l}\text { Beatty } \\
\text { Mtn }\end{array}$ & $\begin{array}{c}\text { East of } \\
\text { Beatty } \\
\text { Mtn }\end{array}$ & $\begin{array}{c}\text { Topopah } \\
\text { Spring } \\
\text { NW }\end{array}$ \\
\hline $\begin{array}{c}\text { Daylight } \\
\text { Pass }\end{array}$ & $\begin{array}{l}\text { Gold } \\
\text { Center }\end{array}$ & $\begin{array}{l}\text { Carrara } \\
\text { Canyon }\end{array}$ & $\begin{array}{c}\text { Crater } \\
\text { Flat }\end{array}$ & $\begin{array}{c}\text { Busted } \\
\text { Butte }\end{array}$ \\
\hline
\end{tabular}

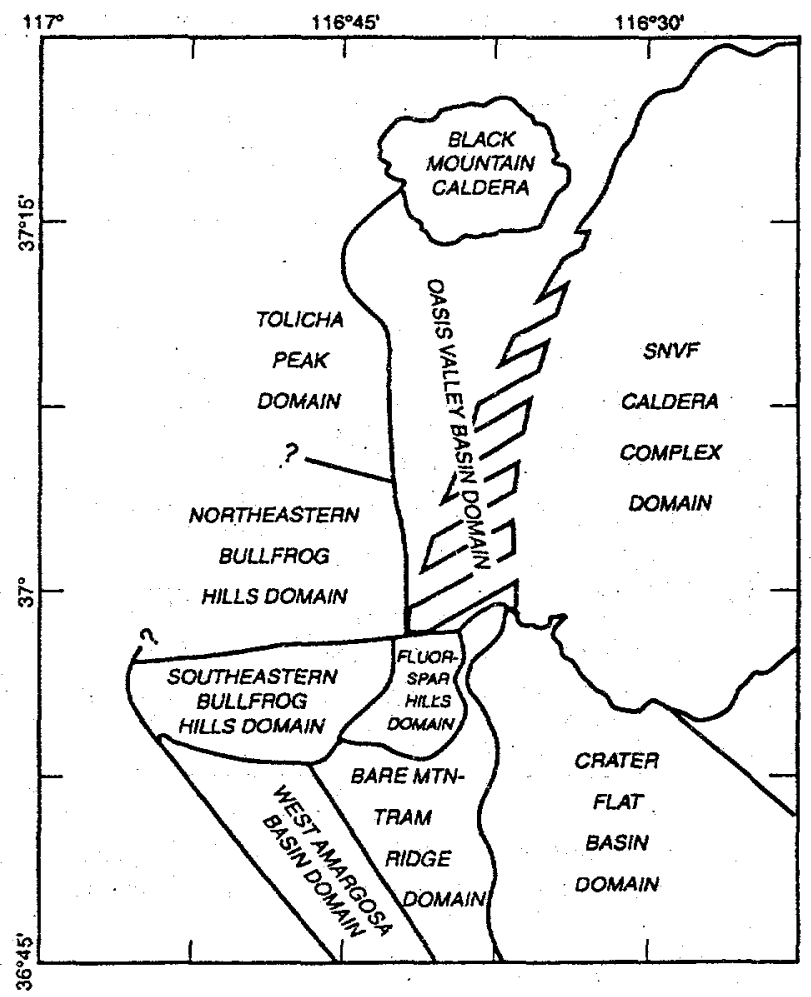

Index map for the Oasis Valley basin and vicinity showing the Pahute Mesa testing area, Oasis. Valley discharge area, caldera outlines, and selected major faults and physiographic features. Figure covers the area of the 9 quadrangle geologic compilation map that is a companion publication for this report (Fridrich and others, 1999-USGS OFR 99-xxx-B), as well as a one-quadrangle-wide perimeter. The two smaller maps show: (1) the 25 quadrangles covered in this figure and (2) a structural domain map. 
more complete version of Monsen and others (1992), excepting that of the Eleana Formation, which was rewritten based on new work by Trexler and others (1996). Mapping of the surficial deposits is a modification from W C Swadley, whose mapping was previously compiled by Wahl and others (1997). Descriptions of the surficial deposit units were written by Slate (Slate and others, 1999).

The cross sections that accompany this map were drawn to a depth of $\sim 5 \mathrm{~km}$ below land surface at the request of hydrologists who are modeling the Death Valley groundwater system. Below a depth of $\sim 1 \mathrm{~km}$, surface constraints offer only faint guidance and the interpretations shown on these sections are therefore constrained primarily by geophysical data. These data also provide the major basis for the positions and magnitudes of faults that are concealed on the surface. Within the Oasis Valley basin alone; the pattern of internal domino-style faulting shown on the cross sections is based on an interpretation of aeromagnetic data, but is strictly schematic. Several small faults that appear on the map were omitted from the cross sections for the sake of clarity.

Geologic Summary

The predominant bedrock units exposed in the Oasis Valley area are widespread middleto late-Miocene ash-flow tuff sheets erupted from the calderas of the southwest Nevada voicanic field. Parts of six calderas are exposed in the map area (see Fig. 1) including the 9.4 Ma Black Mountain caldera and three of the calderas that comprise the Timber Mountain caldera complex the Ammonia Tanks (11.45 Ma), Rainier Mesa (11.6 Ma), and Claim Canyon (12.8-12.7 Ma) calderas (see index map; Byers and others, 1976; 1989; Sawyer and others, 1994). The map area also includes one minor caldera, Twisted Canyon caldera, in the south-central part of the map, and a probable exposure of intracaldera rocks of the 14.3 Ma Tolicha Peak caldera in the northwest corner of the map. The $\sim 11.55 \mathrm{Ma}$ Twisted Canyon caldera is satellitic to, and is probably 
comagmatic with the slightly older Rainier Mesa caldera, as the intracaldera tuff of the Twisted Canyon caldera is petrographically indistinguishable from the Rainier Mesa Tuff (R. Warren, unpub. data). Major ash-flow tuff units in the map area that predate the Claim Canyon caldera range in age from 13.25 to perhaps $15.2 \mathrm{Ma}$ and, excepting the Tuff of Tolicha Peak, have source areas that are concealed. Some of the calderas for these older voluminous tuffs probably lie under the younger Ammonia Tanks, Rainier Mesa, and Claim Canyon calderas.

The major ash-flow tuff units discussed above are intercalated with locally derived rhyolite, basalt, trachyte, and andesite lavas and related tephras, as well as with alluvial and lake sediments, and landslide breccias. This volcanic sequence is overlain by younger alluvium containing relatively minor late-Miocene-to-Quaternary tuffs and basalts, and is underlain by a moderately thick $(\sim 1 \mathrm{~km})$ Tertiary section that predates the southwest Nevada volcanic field and that is largely sedimentary, but that includes minor tuffs. This underlying section is early Oligocene to early Miocene in age and is only locally exposed in the map area. It is mostly known from exposures to the west in the Grapevine and Funeral Mountains (Reynolds, 1961; Fridrich, unpub. data).

The Tertiary section unconformably overlies a largely miogeoclinal section of latest Proterozoic to late Paleozoic sedimentary rocks consisting of limestones, dolomites, argillites, and quartzites. These rocks are exposed in the map area only on Bare Mountain, along the southern boundary of the map, and on a small unnamed uplift in the west-central part of the map area, in the northeastern Bullfrog Hills (see Fig. 1). In addition, a small exposure of rooted Paleozoic carbonate rocks is exposed immediately north of the map area on the western margin of the Black Mountain caldera (see Fig. 1).

The most notable occurrence of Mesozoic rock in the map area is a fault sliver of Cretaceous granite exposed along the northwestern margin of Bare Mountain (Monsen and others, 1992). Hornblende gabbro dikes in northwest Bare Mountain have yielded middle- to late-Tertiary KAr ages, but discordance between the hornblende and biotite ages suggest these are cooling 
ages and these coarse-grained dikes may, in fact, be as old as late Mesozoic. In addition, the latest Proterozoic to late Paleozoic sedimentary rocks of northwest Bare Mountain were moderately to strongly metamorphosed during the Cretaceous (Hoisch and others, 1997).

The Oasis Valley area has a complex tectonic history that includes Mesozoic contractional events and protracted Tertiary extension and strike-slip strain (Fridrich, 1998 and in press). Evidence for Mesozoic contraction in the map area is limited to Bare Mountain and consists of a thrust fault in the northeastern part of the mountain (the Mieklejohn Peak thrust; see Fig. 1; Monsen and others, 1992) and extensive folding of the rocks in the northwestern part of the mountain.

Two detachment faults in northwestern Bare Mountain, named the Gold Ace and Conejo Canyon faults (see Fig. 1), separate strongly metamorphosed rocks of several Cambrian and latest Proterozoic formations, in the common lower plate of these faults, from weakly metamorphosed to nonmetamorphosed rocks of many of the same formations, in the upper plates. This relation indicates at least a two-stage history, involving thrust imbrication and variable metamorphism of these formations in an earlier stage, followed by low-angle normal faulting in a later stage. Strongly metamorphosed and weakly metamorposed-to-nonmetamorphosed rocks of the same formations were in different thrust fault blocks and thus at different levels of the crust when metamorphism occurred. Subsequently, they have been juxtaposed by the two Tertiary detachment faults that are internal to Bare Mountain. Throw of these detachment faults is thus indicated by the metamorphic discordances across them, rather than by displacement of formation boundaries.

Extension and related strike-slip deformation occurred in the map area throughout the second half of the Tertiary Era. This late Tertiary deformation can be divided into three major intervals: (1) deformation that preceded formation of the Fluorspar Canyon-Bullfrog Hills detachment fault system and the related Bare Mountain metamorphic core complex, (2) 
deformation in which this detachment fault system was active, and (3) deformation that postdates activity on this detachment fault system.

Deformation associated with of the Fluorspar. Canyon-Bullfrog Hills detachment fault system is discussed first because most of the structures exposed in the map area formed in this interval, which extends from 12.7 to about $7 \mathrm{Ma}$. Relations in the vicinity of Bare Mountain indicate that this core complex was not uplifted until shortly after $12.7 \mathrm{Ma}$. There is no consistent variation of thickness of the pre-12.7 Ma strata toward this uplift; and the only sediments intercalated with the 14-to-12.7-Ma volcanic units on the flanks of Bare Mountain are very fine-grained, such as marls and mudstones.

Between 12.7 and $11.7 \mathrm{Ma}$, Bare Mountain was abruptly uplifted as is recorded by the emplacement of large wedges of rock-avalanche megabreccia of this age that thicken toward the uplift. These breccias are composed primarily of clasts of Paleozoic rocks, and to a lesser extent of early Miocene and Oligocene formations; the middle Miocene (14-12.7 Mia) rocks are almost completely absent from the breccias. This relation is consistent with Hamilton's (1989) interpretation that Bare Mountain was tectonically denuded of most of its Tertiary section as it was uplifted. Fault-slip indicators on the Fluorspar Canyon-Bulfrog Hills detachment fault at the northern boundary of Bare Mountain indicate that the upper plate was transported to the northwest. Low-silica rhyolite lavas exposed at the $\sim 14$ Ma stratigraphic level in the low hills immediately north of Bare Mountain are petrographically similar to the 14.0 Ma dikes of eastern Bare Mountain (R. Warren, unpub. data). We propose that the dikes of eastern Bare Mountain are the feeders for these lavas, which have been displaced to the northwest, off of Bare Mountain, by slip on the detachment fault.

On the northeastern margin of Bare Mountain, the Fluorspar Canyon-Bullfrog Hills detachment fault bends to the north and, from there, cuts through the volcanic rocks to the northeast of Bare Mountain along a sinuous, generally north-striking trace. In this area to the northeast of Bare Mountain, the currently exposed position of the detachment fault is only slightly 
west of where this fault originally daylighted. To the south, however, the detachment fault is interpreted to have extended over the top of most if not all of the area of Bare Mountain, and it probably extended a short distance into western Crater Flat as well because:

(1) Tertiary clasts are absent from the 12.7-to-11.7-Ma breccias of the Crater Flat basin because the Paleozoic rocks of Bare Mountain were evidently denuded of their Tertiary cover as they were uplifted (Fridrich, 1998 and in press), and

(2) $11.7 \mathrm{Ma}$-and-younger rocks at the southeastern margin of Bare Mountain (south of map area) appear to unconformably overlie early Miocene rocks (Fridrich, unpub. data), suggesting that the middle Miocene section is locally absent in the westernmost part of Crater Flat basin owing to tectonic denudation.

The Bare Mountain range-front fault forms the eastern boundary of the uplifted, tectonically denuded footwall block of the Fluorspar Canyon-Bullfrog Hills detachment fault. Within this footwall block, the degree of metamorphism of the Paleozoic and late Proterozoic lower-plate rocks increases discontinuously to the northwest; Bare Mountain is classic example of a metamorphic core complex (Crittenden and others, 1980). As discussed above, large abrupt changes in metamorphic grade are present across the Gold Ace and Conejo Canyon faults of northwestern Bare Mountain. Within the fault blocks on either side of these internal faults, the degree of metamorphism in the Bare Mountain core complex increases to the northwestward; indicating that the Fluorspar Canyon-Bullfrog Hills detachment fault cut down through the crust to the northwest and was rotated to shallower dips as the upper plate of the detachment was transported to the northwest (as the Bare Mountain uplift was tectonically denuded).

Unmetamorphosed middle Miocene rocks in the upper plate of the detachment, along the north side of Bare Mountain, are thus juxtaposed against Paleozoic and latest Proterozoic rocks having northwestward-increasing degrees of metamorphism in the lower plate. This relation indicates that displacement along the detachment fault increases to the northwest, which is consistent with the fact that the upper-plate rocks were strongly extended between 12.7 and $\sim 10$ 
Ma. The upper-plate rocks are cut by a plexus of normal faults along which the rocks have been tilted, in some cases to roughly vertical dips. The tilting and faulting in the upper plate immediately north of Bare Mountain continued from about 12.7 to about $10 \mathrm{Ma}$, based on fanning dips, angular unconformities, and growth faulting. Normal faults in the upper plate typically are concave upwards (listric), and they sole downward into the Fluorspar Canyon-Bullfrog Hills detachment fault.

Proceeding northwestward from Bare Mountain, the timing of extensional tectonism associated with the Fluorspar Canyon-Bullfrog Hills detachment fault was progressively younger, both in the time of initiation of tectonism and in the time of cessation. The tectonism thus migrated like a wave advancing northwestward through the rocks. The youngest extension that is associated with detachment faulting in this region occurred at about $7 \mathrm{Ma}$ and affected only the northwesternmost part of the map area.

The upper-plate rocks also incurred strong northwest-directed right-lateral strike-slip deformation during movement along the detachment fault. Strike-slip deformation is indicated by significant horizontal components of slip along many of the extensional faults as well as by a small number of mostly-horizontal-motion faults in the upper plate. This strike-slip deformation has also been documented with paleomagnetic data, which show a history of progressive clockwise rotation throughout the interval of extensional deformation (Hudson and others, 1994; unpub. data).

The tilted-domino pattern of extensional faulting along the north side of Bare Mountain continues westward across the Bullfrog Hills and a second, very small metamorphic core complex is exposed in the central Bullfrog Hills to the west of the map area (see Fig. 1). Based on subsurface data gathered in the vicinity of the Barrick-Bulfrog Mine (at '116 48' $45^{\prime \prime} \mathrm{W}$ and $3653^{\prime}$ $45^{\prime \prime} \mathrm{N}$; T. John, oral comm., 1997; Eng and others, 1996) the detachment fault at the top of the Bullfrog Hills core complex is continuous with the detachment fault along the north side of Bare Mountain, in Fluorspar Canyon; hence the name Fluorspar Canyon-Bullfrog Hills detachment fault. Given the magnitude of displacement along this detachment fault, it is reasonable that it extends 
further northwestward than the areas discussed above. We propose that the detachment may underlie all of the west-central part of the map area based on continuity of the gravity high associated with the area of detachment faulting over this whole area (Grauch and others, 1997; written comm., 1999; Hildenbrand and others, 1999; Mankinen and others, 1999), as well as by the structural style in this area, which continues the pattern of extreme extension and significant strike-slip deformation present along the north side of Bare Mountain.

Significant evidence is present in the map area for one or more episodes of extension that preceded the initial $(12.7 \mathrm{Ma}$ ) formation of the Fluorspar Canyon-Bullfrog Hills detachment fault system and the related Bare Mountain metamorphic core complex. In the northwestern part of the map area, oblique extension and clockwise rotation occurred along a set of mostly northeaststriking left-oblique-slip faults between $\sim 14.5$ and $\sim 13 \mathrm{Ma}$ (Minor and Hudson; unpub. data). $A$ number of northeast-striking normal or oblique-slip faults of the same age are buried under Yucca Mountain, southeast of map area, based on gravity and subsurface data (Fridrich, 1998 and in press). Between these two areas, in the area northeast of Bare Mountain, a 25-degree angular unconformity is locally present between the $14.0 \mathrm{Ma}$ Lithic Ridge Tuff and the $\sim 13.5 \mathrm{Ma}$ Tram Tuff. In the Bullfrog Hills, relations in rocks of the 13.5-15.5 Ma range are much less clear; however, the 15.5-to-14-Ma rocks are much more deformed and hydrothermally altered than are adjacent rocks younger than $14 \mathrm{Ma}$.

Tertiary rocks older than $\sim 15.5 \mathrm{Ma}$ are exposed in the map area only in the vicinity of Bare Mountain and around the uplift of Paleozoic rocks in the northeastern Bullfrog Hills. In a small sector graben at the northeast corner of Bare Mountain, a 45-degree angular unconformity is present between the -17-15.5 Ma "green conglomerate" (the upper, early Miocene part of "old fluvial conglomerates" - Tog) and the 15.5-14 Ma rocks of Pavits Spring (Tos). In the northeastern Bullfrog Hills the rocks of this age are all landslid (and are mapped as part of the younger breccias - Tyx), precluding recognition of angular unconformities or other evidence of syndepositional tectonism. Extensional structures related to these pre-12.7-Ma Tertiary tectonic events probably 
are present within Bare Mountain. The Gold Ace and Conejo Canyon detachment faults in particular may have formed in this period based on the fact that these structures are truncated by the Fluorspar Canyon-Bullfrog Hills detachment fault (Fridrich, 1998 and in press).

Evidence of tectonism postdating the Fluorspar Canyon-Bullfrog Hills detachment fault in the map area is limited to minor, widely spaced, mostly north-striking faults that offset the youngest volcanic formations and surficial deposits. Evidence of post-7-Ma tectonism has also been documented along the southern part of the Bare Mountain fault, immediately south of map area, and on Yucca Mountain, to the southeast (USGS, 1996; Fridrich and others, 1998 and in press).

\section{Description of Map Units}

Volcanic rock names were adopted primarily from Minor and others (1993), who used the IUGS total alkali-silica classification (Le Bas and others,1986). Where chemistry is unavailable, volcanic rock names are based on field criteria. Modifiers are sometimes added, such as highsilica rhyolite for rhyolites with $>75 \% \mathrm{SiO} 2$, and quartz trachyte for tuffs that have the majorelement bulk composition of trachyte in the IUGS classification scheme, but that have abundant modal quartz. Phenocryst abundances are median values determined by Warren and others (1998) by point-counting thin sections of samples collected throughout the southwestern Nevada volcanic field, and may therefore represent a broader compositional range than is found in the area of this map. For rocks that vary in porosity (i.e., variable welding in tuffs), the median phenocryst abundances were determined predominantly from dense samples; hence, abundances in nonwelded equivalents have similar proportions of phenocrysts but lower abundances. Descriptions of the Paleozoic and late Proterozoic rock units are modified from Monsen and others (1992), and the reader is referred to that map for more complete descriptions of these units.

Tertiary volcanic nomenclature is modified from Sawyer and others (1994) and the Los Alamos National Laboratory GEODES database (Warren and others, 1998). Reported ages are 
based mainly on ${ }^{40} \mathrm{Ar} /{ }^{39} \mathrm{Ar}$ age determinations (see Wahl and others, 1997, and references therein). Magnetic polarity data were determined primarily by M. Hudson are compiled here from Wahl and others (1997). ).

\section{SURFICIAL DEPOSITS}

Qa Young alluvial deposits (Holocene)-Gravel, sand, and silt; intermixed and interbedded. Grayish brown, pale yellowish brown, light brownish gray to light gray, unconsolidated to poorly consolidated, poorly to moderately well sorted, nonbedded to well bedded, locally cross-bedded. Clasts are commonly angular to subrounded; locaily well rounded. Clasts commonly less than $0.5 \mathrm{~m}$ in diameter, but as much as $2 \mathrm{~m}$ in diameter at and near base of steep slopes, and close to mountain fronts. Sand and silt present as matrix and lenses; rarely form continuous beds. Surface commonly is irregular; bar-and-swale topography and braided channels are common. In places, forms extensive thin sheets of sand with flat, smooth surfaces. Little or no pavement, varnish, or soil development. Maximum thickness about $10 \mathrm{~m}$

Qe Eolian sand deposits (Quaternary) - Silty fine to medium sand, pale yellowish or grayish brown to pale orange, well sorted, massive to poorly bedded; locally includes a few cobbles and pebbles near bedrock outcrops. Forms sheets, ramps, and vegetation-stabilized mounds. Includes varying amounts of eolian sand reworked by slopewash and intermittant streams. Older deposits have soil development. Thickness as much as $30 \mathrm{~m}$

Qp Playa deposits (Holocene)-Silt, fine sand, and clay; poorly to moderately well consolidated, light grayish brown, calcareous, moderately well sorted, thinly bedded, polygonal desiccation cracks common. Locally contains sparse thin beds or lenses of pebbly coarse sand. At least $20 \mathrm{~m}$ thick 
QTC Colluvium (Holocene, Pleistocene, and Pliocene)—Angular to subangular granule- to boulder-sized clasts with variable amounts of sand, silt, and clay as matrix. Generally unsorted and nonbedded to poorly bedded; locally cemented by carbonate. Matrix probably partly of eolian origin. Forms talus deposits and thin mantles of debris along flanks of steep slopes; deposited chiefly by mass-wasting processes. Colluvium-mantled surfaces commonly have ribbed or fluted appearance due to gullying and development of stony surface lags. Locally includes bedrock outcrops too small to map separately. Most deposits are probably of Holocene to middle Pleistocene age. Thickness varies, but generally less than $3 \mathrm{~m}$

QIb Lacustrine beach deposits (Holocene and late Pleistocene)-Pebbly sand beach deposits of late Pleistocene pluvial lakes, which form low discontinuous sand ridges near the playas within the mapped area. Sand is yellowish gray, moderately sorted, mostly medium to coarse, weakly consolidated, slightly pebbly. Ridges are $1-3 \mathrm{~m}$ high, commonly covered with a pebble to coarse-sand lag; surface clasts have a weakly developed desert varnish. Thickness less than $3 \mathrm{~m}$

Qs Middle alluvial deposits (Pleistocene)-Gravel, sand, and silt; intermixed and interbedded, light gray, pinkish gray, and yellowish to grayish brown, weakly to moderately well consolidated. Clasts are unsorted to moderately well sorted, nonbedded to well bedded, angular to rounded. Clasts commonly less than $0.5 \mathrm{~m}$ in diameter, but locally as much as $2 \mathrm{~m}$ in diameter; matrix is sandy to silty. Sand is discontinuously to moderately well bedded, locally crossbedded, moderately well sorted; commonly gravelly and locally silty. Surface is planated with moderately packed to densely packed pavement; pavement clasts are moderately to well varnished. In places, thin eolian sand deposits mantie the surface. Soil development varies from a cambic B horizon and a stage I to II carbonate horizon to an argillic $B$ horizon and an approximately $1-\mathrm{m}$-thick, stage III to IV carbonate horizon. Thickness less than $1 \mathrm{~m}$ to $10 \mathrm{~m}$ 
QTs Old alluvial deposits (Early Pleistocene and Pliocene)-Gravel, sand, and silt; intermixed and interbedded, light brownish gray to light gray. Clasts are angular to subrounded, clasts more than $1 \mathrm{~m}$ in diameter are common at and near base of steep slopes. Generally poorly sorted, nonbedded to poorly bedded, and moderately to well cemented with carbonate. Locally consists of moderately well bedded, poorly to moderately well-sorted pebble to cobble gravel in a sand and silt matrix. Surface is eroded and dissected; commonly forms rounded ridges or ballenas. Where preserved, pavement is generally densely packed and includes tabular fragments cemented by pedogenic carbonate and opaline silica; varnish on pavement clasts is variable but commonly strongly developed. Soils typically consist of a stage III to IV carbonate horizon as much as $2 \mathrm{~m}$ thick; argillic horizons are mostly eroded. Thickness may be greater than $40 \mathrm{~m}$

\section{CENOZOIC BEDROCK}

Qby Recent basalt (Quaternary) - Trachybasalt, black to reddish brown; median $1.7 \%$ total phenocrysts of olivine and rare to absent plagioclase. Occurs in map area as two cinder cones, with associated aa flows, known as Little Black Peak and Hidden cones; only slight dissected. Dated at about 0.35 Ma (Fleck and others, 1996; Crowe and others, 1995). Normal magnetic polarity. Maximum thickness about $200 \mathrm{~m}$

Tgs Older Gravels (early Pliocene and Miocene) -- Yellowish gray to grayish tan gravel deposits, mostly of alluvial-fan origin; poorly to partially consolidated, commonly calcareous; poorly sorted, mostly with sandy matrix, and with local thin interbeds of sandstone and mudstone. Clasts are angular to subrounded, consist of various tuffs, lavas, and sedimentary rocks from surrounding highlands; pebbles predominate but cobbles and boulders up to $2 \mathrm{~m}$ are common; clasts as large as $5 \mathrm{~m}$ are rare. Locally includes intercalated playa deposits in middle part of unit, southeast of Oasis Mountain 
Hogback, as well as widespread minor bedded tuffs and landslide breccias, which are more common in lower part of unit. Deeply dissected but poorly exposed; erosional slopes are typically covered with lag gravels. Unit is generally only slightly tilted and faulted; however, significant faulting and tilting of beds up to 20 degrees is very locally present, in northwestern Crater Flat, in basal parts of the unit that predate an ashfall tuff dated at 10.5 Ma. Unit is everywhere younger than the 11.6 Ma Rainier Mesa Tuff; locally interbedded with some of the Miocene and Pliocene volcanic units of the region, including volcanic rocks of Twisted Canyon caldera ( $11.55 \mathrm{Mz})$, members of the Thirsty Canyon Tuff ( 9.4 Ma), and Spearhead Member of the Stonewall Flat Tuff (7.5 Ma). Locally interfingers at the top with flows of 4.6 Ma basalt of Thirsty Mountain (Typ). Maximum exposed thickness at least $200 \mathrm{~m}$ and probably much thicker locally in the subsurface, in the western part of Oasis Valley basin

Typ Basalt of the Thirsty Mountain shield volcano (Pliocene) - Sequence of black to reddish brown basaltic trachyandesite lavas, lesser scorias, and rare high-level dikes forming a broad, moderately dissected shield volcano at Thirsty Mountain. Median $12.5 \%$ phenocrysts: $7.5 \%$ plagioclase, $5 \%$ olivine, and traces of apatite and clinopyroxene. Reversed magnetic polarity. Dated at $4.63 \mathrm{Ma}$ (Fleck and others, 1996). Linear, northeast-trending master feeder vent is inferred to be largely buried beneath capping lava flows based on the northeast-elongate crest of the shield volcano and roughly coincident pronounced aeromagnetic anomalies (Grauch and others, 1997). Maximum thickness of about $200 \mathrm{~m}$

Tsp Spearhead Member of the Stonewall Flat Tuff (Miocene) -- Mildly peralkaline rhyolite ash-flow tuff; light to very light brown where nonwelded and, rarely, light to medium reddish brown where moderately welded; erupted from Stonewall Mountain caldera at 7.5 Ma (Sawyer and others, 1994). Median 3.2\% phenocrysts: $0.2 \%$ quartz, $2.4 \%$ sanidine, $0.4 \%$ plagioclase, $0.1 \%$ clinopyroxene, and traces of biotite, hornblende, and fayalite. 
Intercalated in Tgs. Commonly concealed on hillsides by colluvial lag gravels derived from overiying Older gravels (Tgs). Tuff is commonly reworked and interbedded with tuffaceous gravel lenses. A thin white ash layer commonly present at base of map unit may be an ashfall deposit related to the rhyolite of Obsidian Butte (Tyr) or to slightly younger, unnamed rhyolite lavas of the western Bullfrog Hills and Grapevine Mountains, to the west of map area. Normal magnetic polarity. Maximum exposed thickness of about $20 \mathrm{~m}$

Tba Younger bedded tuffs (Miocene) - White to cream-colored and light gray nonwelded rhyolite tuffs that are intercalated within Older Gravels (Tgs) in the vicinity of Oasis Mountain, and in northeastern Bullfrog Hills. Tuffs are mostly of ash-fall origin but also include ash-flow and water-lain tuffs, including distal tephas correlative with rhyolite of Rainbow Mountain, rhyolite of Obsidian Butte, and Spearhead Member of the Stonewall Flat Tuff. The lowermost part of this map unit is a lateral equivalent to the uppermost part of the Beatty Wash Formation, mapped further east, as distal tuffs of the rhyolite of Rainbow Mountain are included in both of these collective units. Maximum exposed thickness about $10 \mathrm{~m}$

Tyb Basalts generally of Thirsty Canyon-age (Miocene) - Widespread mafic lava flows, eroded cinder cones, and local feeder dikes erupted from numerous centers between $\sim 10$ and $\sim 8.5 \mathrm{Ma}$. Rocks consist of dark-gray to reddish brown trachybasalt, basalt, and basaltic andesite, and subordinate hawaiite and mugearite. Variable phenocryst content of olivine and plagioclase, and with lesser to absent clinopyroxene, biotite, and orthopyroxene, and rare kaersutitic amphibole and apatite. The majority of these mafic rocks were erupted immediately before, during, or immediately after emplacement of the Thirsty Canyon Tuffs in close proximity to the Black Mountain caldera; however, a number of these basalts interfinger either with the 9.5 to $9.9 \mathrm{Ma}$ rhyolite of Oasis Valley or with the $\sim 8.8 \mathrm{Ma}$ rhyolite of Obsidian Butte. Maximum exposed thickness at least $100 \mathrm{~m}$ 
Tyr Rhyolite of Obsidian Butte (Miocene) -- Generally aphyric, flow-laminated rhyolite lava flows and subordinate related pyroclastic and sedimentary rocks exposed only in the northwest corner of map area. Some flows contain sparse plagioclase and biotite. Dated at $8.8 \mathrm{Ma}$ (Noble and others, 1991). Maximum exposed thickness of about $150 \mathrm{~m}$

Tt Thirsty Canyon Group (Miocene) - Peralkaline assemblage of ash-flow tuffs, lavas, and related nonwelded tuffs erupted from Black Mountain caldera between 9.43 and $9.15 \mathrm{Ma}$. The oldest member of the Group, the comendite of Ribbon Cliff, was emplaced as a precaldera complex of flows and domes. The Pahute Mesa and Trail Ridge Tuffs are the largest volume units and likely are the major, and possibly the only units associated with caldera collapse. Following caldera collapse, trachyte lavas of Pillar Spring (Tts): and the Gold Flat Tuff accumulated in the caldera and the latter overflowed mainly to the north and south (Minor and others, 1998). This Group is everywhere subdivided on the map and so is used as a unit only on the cross sections.

Ttg Tuff of Gold Flat of the Thirsty Canyon Group (Miocene) -- Strongly peralkaline silicic (pantelleritic) welded ash-flow tuff erupted at $9.15 \mathrm{Ma}$, and deposited in and adjacent to the moat of the Black Mountain caldera. Commonly light bluish green on fresh surfaces. Median $12.7 \%$ phenocrysts: $0.4 \%$ quartz, $11.1 \%$ sanidine and lesser anorthoclase, $1 \%$ plagioclase, and traces of clinopyroxene, fayalite, biotite, and arfvedsonite. Contains rare primary fluorite and enigmatite. Anomalous normal magnetic polarity. Maximum thickness of $30 \mathrm{~m}$ in the caldera

Tys Andesite of Sarcobatus Flat (Miocene) -- Local sequence of andesitic lava flows with intercalated minor tuffaceous sedimentary rocks exposed in low hills along the edge of Sarcobatus Flat in northwest part of map area. Lava is medium to dark gray, weathers to dark brown, and is commonly platy and flow-folded with phenocrysts of plagioclase and subordinate orthopyroxene and hornblende. Dated at $9.3 \mathrm{Ma}$ (unpub. data of Fleck cited by Minor and others, 1997). Maximum exposed thickness about $100 \mathrm{~m}$ 

rich to very crystal-rich trachyte to quartz trachyte lava flows, associated tuff and tuff breccia, and porphyritic syenite intrusive rocks; rocks that partly fill and overlap the Black Mountain caldera. Lavas contain abundant to very abundant alkali feldspar (sanidine and lesser anorthoclase), moderately abundant plagioclase, and traces of clinopyroxene, fayalite, and rare biotite. Magnetic polarity is reversed. Maximum exposed thickness of $125 \mathrm{~m}$

Ttt Trail Ridge Tuff of the Thirsty Canyon Group (Miocene) - Widespread welded comendite (peralkaline rhyolite) ash-flow tuff; typically tan or pink where nonwelded; and rusty red or greenish brown where welded. Median 13\% phenocrysts: $12 \%$ sanidine and lesser anorthoclase, $0.5 \%$ plagioclase, and traces of clinopyroxene, fayalite, and quartz. Anomalous reversed magnetic polarity. Maximum exposed thickness about $80 \mathrm{~m}$

Ttp Pahute Mesa Tuff of the Thirsty Canyon Group (Miocene) -- Comendite ash-flow tuff; typically tan or pink where nonwelded; and rusty red or greenish brown where welded. Median $4.9 \%$ phenocrysts: $0.1 \%$ quartz, $4.4 \%$ sanidine and lesser anorthoclase, $0.2 \%$ plagioclase, and about $0.1 \%$ each of Fe-rich clinopyroxene and fayalite. A subjacent and closely related cooling unit, the Rocket Wash Tuff, found north of map area, was dated at 9.4 Ma (Sawyer and others, 1994). Magnetic polarity is anomalous reversed. Maximum exposed thickness of about $35 \mathrm{~m}$

Ttc Comendite of Ribbon Cliff of the Thirsty Canyon Group (Miocene) -- Precaldera crystal-rich to very crystal-rich comendite and trachyte lava flows and domes exposed marginal to the Black Mountain caldera. Median 20.8\%: phenocrysts: $17.9 \%$ sanidine and lesser anorthoclase, $2.9 \%$ plagioclase, and traces of clinopyroxene and fayalite, and rare biotite. Maximum exposed thickness of about $100 \mathrm{~m}$

Tfu Rhyolite of Oasis Valley (Miocene) - Rhyolite lavas and lesser related ashfall and blockand-ash flow tuffs erupted in the Oasis Valley area between 9.9 to $9.5 \mathrm{Ma}$. The lavas 
typically are medium gray whereas the tuffs are white or light tan. Exposed at the mouth of Thirsty Canyon and immediately west of the Transvaal Hills. Median $15.6 \%$ phenocrysts: $4.5 \%$ quartz, $3.8 \%$ sanidine, $3.8 \%$ plagioclase, $0.3 \%$ biotite, and $0.3 \%$ hornblende, and a trace of clinopyroxene. Maximum exposed thickness of about $70 \mathrm{~m}$

Tfmu Volcanic units intervening between the Ammonia Tanks and Pahute Mesa Tuffs in Oasis Valley basin (Miocene) - Collective unit used only on the cross sections that includes the rhyolite of Oasis Valley and the Beatty Wash Formation

Tfnu Upper Lava of Springdale Mountain (Miocene) - Rhyolite lava forming the upper part of a sequence of late differentiates related to the underlying Trachyte of Donovan Mountain (Tfny); Lava is light gray, flow-banded and -foliated, locally lithophysal, and contains abundant sanidine, sparse plagioclase, biotite and rare clinopyroxene phenocrysts. Commonly vitrophyric at the base; map unit locally includes a nonwelded to moderately welded trachyte ash-flow tuff. Maximum preserved thickness about $150 \mathrm{~m}$

Tfnl Lower Lava of Springdale Mountain (Miocene) - Dacite lava forming the lower part of a sequence of late differentiates related to the Trachyte of Donovan Mountain. Lava is medium to dark gray, weathering to dark brown; flow foliated and folded, with sparse to abundant sanidine and plagioclase, biotite and lesser clinopyroxene. Includes local pyroclastic deposits. Maximum exposed thickness about $125 \mathrm{~m}$

Tfnb Tuffaceous sedimentary breccia of Springdale Mountain (Miocene) - Poorly to moderately well bedded breccia, conglomerate, pebbly sandstone, and minor siltstone with a reworked tuffaceous matrix, and rare thin interbeds of silicic ash-fall tuff. Contains subangular clasts as large as $0.5 \mathrm{~m}$, mostly of trachyte of Donovan Mountain. Maximum exposed thickness about $35 \mathrm{~m}$

Tfny Trachyte of Donovan Mountain (Miocene) -- Sequence of crystal-rich mafic trachyte flows, and lesser local basaltic flows in the southwestern part of map area. Flows are $\sim 10$ $\mathrm{m}$ thick on average and form resistant ledges owing to alternation of dense flow interiors 
with rubbly, oxidized flow tops and bases. Trachyte is dark brown to dark gray or red (in oxidized flow margins) and has median $19.8 \%$ phenocrysts: $10.4 \%$ plagioclase, $7.6 \%$ sanidine, $0.8 \%$ biotite, and $0.8 \%$ clinopyroxene. Normal magnetic polarity; dated at 10.4 Ma (Saywer and others, 1994). Maximum exposed thickness about $300 \mathrm{~m}$

Trl/Trt Rhyolite of Rainbow Mountain (Miocene) -- Rhyolite lavas (Trl) and related tuffs (Trt), including ash-flow, block-and-ash flow, ashfall, and waterlain tuffs, erupted from vent areas in eastern Bullfrog Hills in southwest part of map area. Stratigraphic constraints and existing geochronology suggest this sequence dates from about 10.5 to $11 \mathrm{Ma}$ (Connors and others, 1998). Ranges from crystal-poor to crystal-rich and from high-to low-silica rhyolite in composition. Distinguished from other post-11 Ma quartz- and biotite-bearing rhyolites of the southwest Nevada volcanic field by a very high plagioclase-to-sanidine ratio (sanidine commonly absent) and by the absence or rarity of hornblende except in the lowest-silica and most crystal-rich emplacement units. Locally, Trt includes partly consolidated alluvium that is interbedded with the tuffs near the base of this unit. Maximum exposed thickness of at least $400 \mathrm{~m}$

Tri Felsic intrusions related to rhyolite of Rainbow Mountain (Miocene) - Intrusive rhyolite ranging in texture from crystal-poor flow-banded rhyolite to crystal-rich porphyry with an aphanitic groundmass; typically strongly hydrothermally altered

T.yx Younger landslide breccias (Miocene) -- Includes both rock-avalanche breccias and giant gravity-slide blocks in the west-central and southern part of map area. In the northern Bullfrog Hills, breccias are locally overlain directly by tuffs that are petrographically correlated with to the upper part of the Rainbow Mountain rhyolite, and include bedded tuffs, between breccia emplacement units, that probably are correlative with the lower part of the Rainbow Mountain rhyolite but that are too altered to identify with any certainty. Elsewhere, breccias of this map unit are older, such as at Oasis Mountain where they underlie the Ammonia Tanks Tuff. Most if not all of the older breccias of this group include 
clasts of Rainier Mesa Tuff. Breccia clasts and slide blocks include rock units ranging from Paleozoic sedimentary rocks through the entire sequence of Tertiary units that predate the Rainbow Mountain. Breccias are highly variable in color but most commonly are bleached white or stained bright red owing to common strong hydrothermal alteration. Thickness uncertain because tilting and especially faulting are difficult to discern in the breccias

TId Lavas of Dome Mountain (Miocene) - Black vesiculated trachybasalt and trachyandesite lava with phenocrysts of olivine, plagioclase, and lesser clinopyroxene. One small exposure in the southeastern part of map area is the westernmost tip of a large mesa-like volcanic edifice (Dome Mountain) of basaltic lavas formed in the southern moat of the Ammonia Tanks caldera between $\sim 11$ and $10 \mathrm{Ma}$. A larger exposure in map area is a separate, petrographically correlated volcanic edifice in the northwestern moat of the same caldera. Exposed thickness in map area is about $35 \mathrm{~m}$

Tfw Beatty Wash Formation - Sequence of nonwelded rhyolitic bedded tuffs (Tfw), the lowest of which are related to the youngest lavas of the Timber Mountain group (rhyolite of Beatty Wash lavas - Tfl) and the youngest of which are distal tuffs of the rhyolite of Rainbow Mountain. Includes interbeds of tuffaceous alluvium and of breccias derived from lavas of the Beatty Wash rhyolite. Maximum exposed thickness at least $200 \mathrm{~m}$

Tfb Basalts erupted between $\sim 11.4$ and $\sim 10.5$ Ma (Miocene) -- Black to dark gray extrusive rocks $(\mathrm{Tfb})$, including vesiculated-to-dense lavas and reddened flow-margin breccias and scorias, and related feeder dikes. Stratigraphically constrained as being roughly coeval with or younger than the youngest unit of the Timber Mountain Group (tuff of Cutoff Road Tfc) and older than the Donovan Mountain Latite. Also includes basalts that are not well constrained stratigraphically but that fall in the same age range based on radiometric dates. Locally contains interbeds of alluvium, rock-avalanche breccia (Tfx), and - locally the tuff of Cutoff Road. Contains moderate amounts of plagioclase, olivine, and lesser clinopyroxene phenocrysts. Maximum exposed thickness of about $500 \mathrm{~m}$ 
Tfc Tuff of Cutoff Road (Miocene) - Rhyolite ash-flow tuff, pink, incipiently welded. Median $10.6 \%$ phenocrysts: $4.6 \%$ sanidine, $5.2 \%$ plagioclase, $0.7 \%$ biotite, $0.1 \%$ sphene, trace of hornblende and noteably contains almost no quartz. Normal magnetic polarity. Maximum exposed thickness of about $250 \mathrm{~m}$

Tft2 Upper tuff of Fleur-de-Lis Ranch (Miocene) - Rhyodacitic weided ash-flow tuff, typically greenish gray or brownish gray, and containing median $15.5 \%$ phenocrysts of $13.4 \%$ plagioclase, $0.4 \%$ sanidine, $1.5 \%$ biotite, and $0.2 \%$ clinopyroxene. Uppermost of three petrographically indistinguishable units erupted on the west side of the Timber Mountain caldera complex and consisting of a lava sequence sandwiched between two tuffs. Normal magnetic polarity. Maximum exposed thickness of about $200 \mathrm{~m}$

Tfr Lavas of Fleur-de-Lis Ranch and of West Cat Canyon (Miocene) - Map unit includes two physically separated but petrographically, chemically, and temporally similar sequences of rhyodacitic lava flows. The lava of Fleur-de-Lis Ranch is exposed on the northern half of the Oasis Mountain, whereas the lava of West Cat Canyon is exposed in the western moat of the Ammonia Tanks caldera. Both have normal magnetic polarity. Maximum exposed thicknesses of about $350 \mathrm{~m}$ for the lava of Fleur-de-Lis Ranch and about $250 \mathrm{~m}$ for the lava of West Cat Canyon

Tft1 Lower tuff of Fleur-de-Lis Ranch (Miocene) - Rhyodacitic welded ash-flow tuff that is petrographically indistinguishable from the upper tuff of Fleur-de-Lis Ranch and that is distinuished based on stratigraphic position and magnetic polarity. Reversed magnetic polarity. Maximum exposed thickness of about $150 \mathrm{~m}$

Tfs Lake sediments of Oasis Mountain (Miocene) - Interbedded shale, sandstone, marl, and freshwater limestone, all tuffaceous; ivory, ochre, yellow-green, and tan in color; thinly laminated, with ripple marks and mud cracks locally preserved. Mapped only on Oasis Mountain where it overlies Ammonia Tanks Tuff and underlies the lower tuff of Fleur-de-Lis Ranch. Maximum exposed thickness of about $80 \mathrm{~m}$ 
Timber Mountain Group (Miocene) - Assemblage of rocks that range in composition from highsilica rhyolite to trachyte and that were erupted from the Timber Mountain caldera complex between 11.7 and $11.4 \mathrm{Ma}$. Includes two very large volume ash-flow tuffs, the Ammonia Tanks and Rainier Mesa Tuffs, as well as numerous minor tuffs and lavas erupted before, after, and between emplacement of these major caldera-forming eruptive units

\section{Tmai Subcaldera intrusion of the Ammonia Tanks caldera (Miocene) - Batholithic} Intrusion inferred to be present under the Ammonia Tanks caldera and shown only on the cross sections. The geometry of this body is based on a model of the gravity data (Hildenbrand and others, 1999). Hypabyssal microgranite intrusions that may be cupolas of this batholith are exposed locally on the east flank of Timber Mountain, about $4 \mathrm{~km}$ east of map area

Tfl Rhyolite of Beatty Wash (Miocene) - Post-caldera rhyolite lavas erupted in the moat of the Ammonia Tanks caldera; typically gray, red, or black (where vitreous), and moderately crystal rich with subequal sanidine and plagioclase, biotite, conspicuous. sphene, sparse hronblende, and rare local quartz. Normal magnetic polarity. Maximum exposed thickness of at least $50 \mathrm{~m}$

Tma Ammonia Tanks Tuff of the Timber Mountain Group (Miocene) -- Crystal-rich, most commonly lavender-gray, welded ash-flow tuff erupted at $11.45 \mathrm{Ma}$ (Sawyer and others, 1994) from Ammonia Tanks caldera. Compositionally zoned from lower high-silica rhyolite (median $17.5 \%$ total phenocrysts: $3.8 \%$ quartz, $11.2 \%$ sanidine, $2.3 \%$ plagioclase, $0.2 \%$ biotite, $0.01 \%$ clinopyroxene, with commonly cryptic (small, sparse sphene) to upper quartz trachyte (median $24.5 \%$ total phenocrysts: $2.7 \%$ quartz, $13.0 \%$ sanidine, $7.5 \%$ plagioclase, $1.1 \%$ biotite, $0.25 \%$ clinopyroxene, with conspicuous sphene). Commonly difficult to distinguish from the Rainier Mesa Tuff; distinguished by its higher stratigraphic position, normal magnetic polarity, presence of sphene as well as common basalt lithics and chatoyant sanidine. Unusual features of this unit in the map area include strong 
rheomorphic lineation near the crest of Oasis Mountain and high abundance of lithics on the Hogback immediately south of Oasis Mountain. Maximum exposed thickness of at least $1000 \mathrm{~m}$ on Oasis Mountain

Tmb Basalts of Timber Mountain age (Miocene) -- Black to reddish brown basalt lavas and lesser scoria deposits and feeder dikes emplaced between eruptions of the Rainier Mesa and Ammonia Tanks Tuffs. Typically phenocryst-poor with $>5 \%$ olivine and lesser plagioclase phenocrysts. Maximum exposed thickness of about $60 \mathrm{~m}$

Tmri Subcaldera Intrusion of the Rainier Mesa Caldera (Miocene) - Batholithic Intrusion inferred to be present under the Rainier Mesa caldera and shown only on the cross sections as it is nowhere exposed. The geometry of this body is based on a model of the gravity data (Hildenbrand and others, 1999)

Tmat Rhyolite of Tannenbaum Hill of the Timber Mountain Group (Miocene) - Rhyolite lavas emplaced in the moat of the Rainier Mesa caldera prior to the caldera-forming eruption of the Ammonia Tanks Tuff. Median about $8 \%$ phenocrysts: $3 \%$ quartz, $5 \%$ sanidine, traces of plagioclase and biotite, and conspicuous sphene. Typically gray, commonly flow banded. Maximum exposed thickness of about $100 \mathrm{~m}$

\section{Tmrx Breccias associated with Timber Mountain Tuffs (Miocene)—Caldera-collapse}

breccias associated with the Rainier Mesa and Twisted Canyon Tuffs; typically bright red or bleached white where hydrothermal altered or dark purplish brown where relatively unaltered. In the Transvaal Hills, caldera-collapse breccia is intercalated with the intracaldera Rainier Mesa Tuff and consists predominantly of large, internally shattered clasts of Paintbrush Group Tuffs: Similar breccias are exposed along the southwestern margin of the Rainier Mesa caldera. Caldera-collapse breccias also form an inboardthinning wedge around the eastern margin of the Twisted Canyon caldera, in south-central part of map area; these breccias are composed predominantly of clasts of Rainier Mesa 
Tuff and of lavas of the rhyolite of Fluorspar Canyon. Maximum exposed thickness of about $70 \mathrm{~m}$ in the southern Transvaal Hills

\section{Tmt Tuffs and lavas of the Twisted Canyon caldera, of the Timber Mountain Group} (Miocene) - A sequence of volcanic rocks, erupted in the Twisted Canyon caldera at $\sim 11.55 \mathrm{Ma}$, which includes one rhyolite ash-flow tuff unit, and numerous rhyolite lavas and related ash-fall tuffs emplaced above and below the ash-flow. The ash-flow tuff is petrographically and chemically indistinguishable from the Rainier Mesa Tuff but is clearly a separate unit because it includes lithics and wedges of caldera-collapse breccia composed of poorly to densely welded Rainier Mesa Tuff. Exposed only as the fill of the Twisted Caldera. This caldera fill also includes some interbedded alluvium which is included in map unit, caldera-collapse breccias (Tmrx), and two small dissected olivine basalt cinder cones (Tmb). Maximum exposed thickness of about $140 \mathrm{~m}$

Tmr Rainier Mesa Tuff of the Timber Mountain Group (Miocene) -- Crystal-rich welded ash-flow tuff erupted at 11.6 Ma from Rainier Mesa caldera. Compositionally zoned from lower high-silica rhyolite (median $4.0 \%$ quartz, $4.3 \%$ sanidine, $1.9 \%$ plagioclase, and $0.1 \%$ biotite) to upper more crystal-rich quartz trachyte (median $23.9 \%$ total phenocrysts: $3.3 \%$ quartz, $9.9 \%$ sanidine, $9.3 \%$ plagioclase, $1.2 \%$ biotite, $0.2 \%$ clinopyroxene, and traces of hornblende and orthopyroxene). Unit distinguished from Ammonia Tanks Tuff by high quartz content, rare accessory monazite, and lack of sphene. Lower nonwelded zone is salmon pink; welded part is brown, gray, or red. Reverse magnetic polarity. Maximum exposed thickness of at least $250 \mathrm{~m}$

\section{Tmrf Rhyolite of Fluorspar Canyon of the Timber Mountain Group (Miocene) - A} sequence of mostly white to pink nonwelded tuffs, including ash-flow, ash-fall, surge, and waterlain tuffs, as well as related, petrographically similar, typically gray lavas, all of highsilica rhyolite composition. Several eruptive units of this group have yielded ages ranging from 11.62 to $11.7 \mathrm{Ma}\left({ }^{40} \mathrm{Ar}{ }^{39} \mathrm{Ar}\right.$, sanidine; Sawyer and others, $1994 ; \mathrm{M}$. A. Lanphere, 
USGS, unpub. data). The syntectonic nature of this unit is reflected in prevalent fanning dips, locally with as much as 35 degrees of decrease in dips upsection, as well as common interfingering of this unit with older landslide breccias (Tox). A small fraction of the tuffs and lavas in this map unit are petrographically similar to the first-erupted part of the Rainier Mesa Tuff, whereas the majority are much more evolved and crystal-poor. Median phenocryst assemblage for the dominant crystal-poor facies is $5.5 \%$ total phenocrysts: $2.1 \%$ quartz, $2.0 \%$ sanidine, $1.3 \%$ plagioclase, and $\sim 0.1 \%$ biotite. Maximum exposed thickness of about $400 \mathrm{~m}$

Tox Older landslide breccias (Miocene) -- Rock-avalanche megabreccias and subordinate talus breccias deposited before emplacement of the 11.6 Ma Rainier Mesa Tuff. The dominant volume was deposited in a major tectonic event between 12.7 and 11.6 Ma. Most breccias of this interval are composed of clasts of Tiva Canyon Tuff and of other units of the Paintbrush Group. One large breccia wedge of this age is exposed along the north side of Bare Mountain and is composed dominantly of clasts of early Miocene and Oligocene sediments (Tos and Ttc), $14 \mathrm{Ma}$ quartz-trachyte porphyries (Tli), and Paleozoic carbonate rocks. In the north-central part of map area, breccias of this unit predate the 12.7 Ma Tiva Canyon Tuff, mantle the eroded scarp of the Hogback fault (see index map), and are composed mainly of clasts of Quartz Mountain lavas and Tuff of Sleeping Butte. Maximum exposed thickness of at least $100 \mathrm{~m}$

Tps Sedimentary caldera fill -- Tuffaceous sedimentary breccias and waterlain tuffs that fill the moat of Claim Canyon caldera, source of the Paintbrush Group. Most of the tuffaceous material in this unit is probably derived from the rhyolite of Windy Wash based on phenocryst assemblage. Stratal tilts in this unit indicate that much of the exposed sequence was deposited during caldera resurgence; dips reflect resurgent doming but are significantly less than the dips in the underlying intracaldera Tiva Canyon Tuff. Thickness uncertain owing to poor exposure 
Tpn Rhyolite of Windy Wash (Miocene) - Predominantly a complex of rhyolite lava domes and related tuffs (Tpn) erupted in the southern moat of the Claim Canyon caldera. The lavas are typically light gray or tan whereas the tuffs are off- white; from a distance, both are a yellow-greenish cream color. The main group of flows have a median of $20.5 \%$ phenocrysts: $5 \%$ quartz, $9.6 \%$ sanidine, $5.4 \%$ plagioclase, $0.4 \%$ biotite, and $0.05 \%$ sphene; whereas the lesser uppermost group of flows have a median of $14.6 \%$ phenocrysts: $5.1 \%$ quartz, $5.2 \%$ sanidine, $3.7 \%$ plagioclase, $0.6 \%$ biotite, and no sphene. The oldest flows and tuffs appear to be slightly tilted by resurgent doming of the caldera; whereas the youngest flows, which have been dated at about $12.5 \mathrm{Ma}$, are apparently untilted. Maximum exposed thickness of about $200 \mathrm{~m}$

Tpi Intrusive facies of rhyolite of Windy Wash (Miocene) - Feeder dikes for the lavas and tuffs, many of which have both massive and pyroclastic facies within single dikes. Most dikes are emplaced in faults formed during resurgence of Claim Canyon caldera and cut the intracaldera Tiva Canyon Tuff. The intrusive/extrusive transition is locally exposed.

Tp Paintbrush Group (Miocene) - Sequence of alkali rhyolite to trachyte tuffs and lavas erupted from the Claim Canyon caldera between 12.8 and 12.7 Ma. Group is lumped as one map unit only on cross section B-B', where it includes a lava sequence that postdates the Tiva Canyon Tuff but that petrographically resembles the crystal-rich trachyte subunit (Tpcr) of that formation

Tpx Breccias associated with Paintbrush Group Tuffs (Miocene)-Caldera-collapse breccias that crop out as wedges and irregular masses intercalated in all three subunits of the Tiva Canyon within the Claim Canyon caldera. Consist predominantly of large, internally shattered clasts of volcanic units predating Tiva Canyon Tuff, but especially of the Yucca Mountain and Topopah Spring Tuffs, most commonly in a matrix of nonwelded Tiva Canyon Tuff. The largest exposure is in the northwestern moat of the Claim Canyon caldera, where giant (commonly $>100 \mathrm{~m}$ ) lenticular breccia masses are suspended in a 
matrix of nonwelded tuff and are aligned parallel to the subvertical caldera margin.

Maximum exposed thickness of at least $100 \mathrm{~m}$

Tpc Tiva Canyon Tuff of the Paintbrush Group (Miocene) -- Voluminous, densely welded ash-flow tuff erupted at $12.7 \mathrm{Ma}$ from Claim Canyon caldera. Reverse magnetic polarity. Unit is compositionally zoned from lower crystal-poor high-silica rhyolite to upper crystalrich trachyte, wherein the compositional change between these two map units typically is developed over 1 to $5 \mathrm{~m}$ with no cooling break. Locally, the mafic-upward compositional zonation is repeated above a partial cooling break and the subunit above that break has been called the Tuff of Pinyon Pass (Christiansen and Lipman, 1965), which is only very locally preserved outside the Claim Canyon caldera, but it is mapped (as Tpcy) in the major extracaldera exposure (at about $11637^{\prime} \mathrm{W}$ and $3658^{\prime} \mathrm{N}$ ). Within the Claim Canyon caldera alone, Tiva Canyon Tuff is divided into three compositional subunits, all of which are different mixtures of the same bimodal group of high-silica rhyolite and trachyte pumice lapilli and ash. Maximum exposed thicknesses of the whole unit (Tpc) inside and outside the caldera are at least $1500 \mathrm{~m}$ and at least $200 \mathrm{~m}$, respectively Tpcy Tuff of Pinyon Pass subunit of Tiva Canyon Tuff - Low-silica rhyolite; typically. medium rusty red where densely welded and light yellow where nonwelded.

Compositionally intermediate between the crystal-rich trachyte and the crystal-poor rhyolite subunits, described below. Bulk tuff varies from about a 95-5 to a $70-30$ mixture of highsilica rhyolite and trachyte pumice lapilli and ash, from the base to the top respectively Tpcr Crystal-rich trachyte subunit of Tiva Canyon Tuff -- Typically dark rusty brown, dark red, or dark purplish gray; and densely welded throughout. Median $\sim 13.5 \%$ total phenocrysts: about $10 \%$ sanidine, $3 \%$ plagioclase, $0.5 \%$ biotite, $0.2 \%$ clinopyroxene, traces of sphene, fayalite, and rare hornblende and quartz. Bulk tuff is roughly a $70-30$ to $50-50$ mixture of high-silica rhyolite and trachyte pumice lapilli and ash, respectively 
Tpcp Crystal-poor rhyolite basal subunit of Tiva Canyon Tuff -- Typically light gray or light to medium red, very lithic-poor, densely welded except at the base. Outside the caldera, this subunit is characteristically strongly lithophysal near upper contact with Tpcr. Median $3.0 \%$ total phenocrysts: $2.9 \%$ sanidine, and traces of clinopyroxene, plagioclase, sphene, biotite, and rare hornblende and quartz. This subunit is almost purely derived from high-silica rhyolite pumice lapilli and ash, but locally includes rare $(<1 \%)$ trachyte pumices in upper part

Tpy Yucca Mountain Tuff of the Paintbrush Group (Miocene) -- Welded high-silica rhyolite ash-flow tuff that is aphyric (median $<0.1 \%$ phenocrysts of sanidine, biotite, plagioclase, and sphene) but that otherwise resembles the lower rhyolitic part of Tiva Canyon Tuff in range of colors, welding, lithophysae development, and groundmass crystallization in hand specimens. From a distance, the Yucca Mountain Tuff appears dark brown as compared to the rusty medium brown of the Tiva Canyon Tuff. Reversed magnetic polarity. Maximum exposed thickness of about $200 \mathrm{~m}$ inside the Claim Canyon caldera and about $75 \mathrm{~m}$ outside

Tpet Rhyolite of Echo Peak of the Paintbrush Group (Miocene) -- Consists of a rhyolite lava flow and petrographically similar overlying ash-flow tuff found in map area only inside the Claim Canyon caldera. Median $10.8 \%$ phenocrysts: $0.14 \%$ quartz, $6.3 \%$ sanidine, $3.8 \%$ plagioclase, $0.5 \%$ biotite, and traces of clinopyroxene and sphene. Reversed magnetic polarity. Maximum exposed thickness of about $300 \mathrm{~m}$

Tpp Pah Canyon Tuff of the Paintbrush Group (Miocene) -- Variably welded low-silica rhyolite ash-flow tuff with two partial cooling breaks evident in many exposures. Typically light to dark rusty orange or brownish medium gray where very thick - inside Claim Canyon caldera. Median $7.3 \%$ phenocrysts: $0.1 \%$ quartz, $3.3 \%$ sanidine, $3.5 \%$ plagioclase, $0.4 \%$ biotite, and traces of clinopyroxene and rare sphene. Reversed magnetic polarity. Maximum exposed thickness of about $200 \mathrm{~m}$ inside the caldera, and $<40 \mathrm{~m}$ outside 
Tpt Topopah Spring Tuff of the Paintbrush Group (Miocene) -- Voluminous welded ashflow tuff sheet erupted at 12.8 Ma from Claim Canyon caldera; light orange (nonwelded base) to dark olive brown (welded) in color, or black where dense and vitrophyric. Compositionally zoned from lower crystal-poor, high-silica rhyolite (median $1.0 \%$ total phenocrysts: $0.3 \%$ sanidine, $0.6 \%$ plagioclase, $0.03 \%$ biotite, and trace quartz) to upper crystal-rich trachyte (median $11.6 \%$ total phenocrysts: $7.2 \%$ sanidine, $3.8 \%$ plagioclase, $0.45 \%$ biotite, $0.12 \%$ clinopyroxene, and $<0.1 \%$ quartz). Distinguished from the Tiva Canyon Tuff by absence of sphene and lower minimum phenocryst abundance (comparing the lower, rhyolitic parts). Very locally contains well rounded inclusions of light greenish gray Miocene granite in several sites around the margins of the Claim Canyon caldera. At one of these sites, near a locality named Prospector's Pass in northwestern Crater Flat, an additional compositional (hornblende-bearing) subunit is locally present at the top of the tuff and consists of a largely vitrophyric section with six partial breaks. Where lithophysal, the characteristic vug size in Tpt is $\sim 10 \mathrm{~cm}$, as compared to $\sim 5 \mathrm{~cm}$ for Tpc. Normal magnetic polarity. Maximum exposed thickness of about $180 \mathrm{~m}$

Tht Calico Hills Formation (Miocene) -- Sequence of numerous thin high-silica rhyolite blockand-ash flows and other bedded tuffs, typically very light yellow, characteristically zeolitized and bearing abundant lithic fragments of flow-banded red and gray lava that is petrographically similar to the tuffs. Predominant crystal-poor facies has median $2.3 \%$ total phenocrysts: $0.9 \%$ quartz, $0.9 \%$ sanidine, $0.45 \%$ plagioclase, $0.04 \%$ biotite. Dated at 12.9 Ma (Sawyer and others, 1994). Maximum exposed thickness of about $100 \mathrm{~m}$

Tc Crater Flat Group (Miocene) - Sequence of metaluminous rhyolite tuffs and lavas erupted between 13.5 and $13.1 \mathrm{Ma}$ (Sawyer and others, 1994). Collective unit used only on cross section $\mathrm{B}-\mathrm{B}^{\prime}$

Tcb Bullfrog Tuff of the Crater Flat Group (Miocene) -- Rhyolite ash-flow tuff; generally lavender or pale orange where poorly to moderately welded and dark red where densely 
welded. Median $13.3 \%$ total phenocrysts: $2.5 \%$ quartz, $4.7 \%$ sanidine, $5.7 \%$ plagioclase, $0.34 \%$ biotite, and $0.1 \%$ hornblende; wormy resorbed quartz is characteristic. Dated at 13.25 Ma (Sawyer and others, 1994). Normal magnetic polarity. Maximum exposed thickness of about $200 \mathrm{~m}$

Tcr Rhyolite of Prospector's Pass of the Crater Flat Group (Miocene) -- Unit consists primarily of lava flows, which are found only in northwestern Crater Flat, and tuffs, which are interbedded with the lavas and extend several kilometers beyond them.

Petrographically similar to Bullfrog Tuff (Tcb) except that hornblende contents are more variable, ranging from absent to more abundant than in $T c b$. Lavas are flow banded and are typically pale olive gray but local dense parts of flows, which escaped the otherwise pervasive zeolitization, are black, medium green-gray (vitrophyric), or brick red (devitrified). Most tuffs are bedded block-and-ash-flow flow tuffs which are petrographically similar to the lava facies, which contain abundant lithic fragments of the lava facies; and which are pervasively zeolitized. Dated at 13.35 (M. A. Lanphere, USGS, unpub. data). Maximum exposed thickness of at least $100 \mathrm{~m}$

Tct Tram Tuff of the Crater Flat Group (Miocene) -- Rhyolite ash-flow tuff, mostly densely. welded. Median $10.6 \%$ total phenocrysts: $3.6 \%$ quartz, $3.2 \%$ sanidine, $3.4 \%$ plagioclase, $0.4 \%$ biotite. Dated at $13.4 \mathrm{Ma}$. Reversed magnetic polarity. Maximum exposed thickness of at least $250 \mathrm{~m}$ in northwestern Crater Flat

Tbg Grouse Canyon Tuff of the Belted Range Group (Miocene) - Peralkaline rhyolite (comendite) welded ash-flow tuff erupted from Silent Canyon caldera complex at 13.7 Ma. Basal ash-fall tuff is white; welded ash-flow tuff is typically dark rusty red, greenish black (vitrophyre), or dark bluish green where densely welded and devitrified but not oxidized. Compositionally zoned from lower aphyric comendite to upper crystal-rich comendite. Median $0.5 \%$ phenocrysts, mostly alkali feldspar, with rare quartz, plagioclase, clinopyroxene, and fayalite. Groundmass arfvedsonite is common in devitrified welded 
upper part. Anomalous normal magnetic polarity. Maximum exposed thickness of $100 \mathrm{~m}$ in northwestern part of map area

Tob Older basalts (Miocene) - Olivine basalts consisting of thin, localized flows immediately below the Grouse Canyon Tuff. Maximum exposed thickness of about $20 \mathrm{~m}$

Tit Lithic Ridge Tuff (Miocene) -- Rhyodacitic ash-flow tuff, poorly to moderately welded, and characteristically very rich in intermediate-composition lithic fragmments. Typically greenish gray or yellow-greenish tan. Median of $9.5 \%$ phenocrysts: $0.5 \%$ quartz, $3.4 \%$ sanidine, $5.3 \%$ plagioclase, $0.26 \%$ biotite, and conspicuous sphene. Locally included in unit are numerous thin nonwelded bedded tuffs that directly underlie the ash-flow tuff, and that resemble it petrographically. Anomalous reverse magnetic polarity. Maximum exposed thickness of about $200 \mathrm{~m}$

Tli Intrusive facies, Rhyolite of Picture Rock (Miocene) -- Dikes emplaced in eastern Bare Mountain that are the presumed feeders for the Tlp lavas, described below, based on petrographic similarity; dated at 14.0 Ma (Sawyer and others, 1994)

Tlp Lavas and associated tuffs, Rhyolite of Picture Rock (Miocene) -- Rhyodacitic to dacitic, and lesser rhyolitic lava flows, typically dark gray-green, maroon, gray, or dark brown and coarsely porphyritic, and related ochre and light green bedded tuffs. Related to the Lithic Ridge Tuff based on petrographic similarity. Median $17.4 \%$ total phenocrysts: $0.2 \%$ quartz, $0.7 \%$ sanidine, $15.0 \%$ plagioclase, $1.3 \%$ biotite, $0.17 \%$ hornblende, and $0.01 \%$ sphene. Reversed magnetic polarity. Maximum exposed thickness of about $200 \mathrm{~m}$

Tqc Late rhyolite of Quartz Mountain (Miocene) -- Rhyolite lava flows and associated tephra envelope; flow-foliated and-banded, partly vitric. Crystal-poor with sparse alkali feldspar and rare plagioclase and clinopyroxene. Exposed only in the northwestern part of map area where unit has a maximum exposed thickness of about $60 \mathrm{~m}$

Tqs Tuff of Sleeping Butte (Miocene) -- Sequence of two lithic-rich rhyolite ash-flow tuffs and associated ash-fall tuffs exposed mainly in the northwest part of map area; distal facies are 
included in units Tot and Tos, described below. The lower of the two tuffs is thicker, more widespread, more densely welded, and is zoned from a lower mafic-poor rhyolite to an upper mafic-rich and phenocryst-rich low-silica rhyolite. Lower tuff has a median of $18.9 \%$ phenocrysts: $4.2 \%$ quart, $9.5 \%$ sanidine, $4.6 \%$ plagioclase, $0.4 \%$ biotite, and $0.24 \%$ hornblende, and locally includes characteristic alaskitic granite lithics. Upper tuff is petrographically similar. Dated at $14.3 \mathrm{Ma}$. Normal magnetic polarity. Maximum exposed thickness of about $1000 \mathrm{~m}$

Tqh Middle rhyolite of Quartz Mountain (Miocene) - Rhyolite to lesser dacite lava flows and related bedded tuffs and local tuffaceous sedimentary rocks; flow-foliated and -banded. Contain phenocrysts of sanidine, plagioclase, quartz, and sparse hornblende. Reverse magnetic polarity. Maximu exposed thickness of about $200 \mathrm{~m}$

Tqt Tuff of Tolicha Peak (Miocene) -- Very crystal- and lithic-poor welded rhyolite ash-flow tuff. Median $0.5 \%$ phenocrysts: plagioclase $>$ sanidine $>$ quartz $>$ biotite. In northwesternmost corner of map area, uppermost part is significantly more phenocryst-rich and especially biotite-rich, and includes internally shattered lithic blocks of older volcanic formations that are as long as $50 \mathrm{~m}$; unit is probably an intracaldera tuff in this locale. Normal magnetic polarity. Dated at $\sim 14.3 \mathrm{Ma}$ (Sawyer and others, 1994). Maximum exposed thickness of at least $300 \mathrm{~m}$

Tot Quartz Mountain Tuffs, unidentified older tuffs, and intercalated sediments (Miocene) - A section of rhyolitic to dacitic ash-flow and ashfall tuffs and lesser sedimentary rocks. Upper part commonly includes the $14.3 \mathrm{Ma}$ tuffs of Sleeping Butte and Tolicha Peak, along with numerous minor tuffs probably related to the Quartz Mountain lavas. Tuffs in lower part are mostly unidentified but include the $\sim 15.2 \mathrm{Ma}$ tuff of Yucca Flat. This sequence of tuffs is interbedded with tuffaceous arkoses, sandstones, shales, and freshwater limestones. Typically strongly altered hydrothermally and ochre-colored. This unit was mapped as the tuff of Sawtooth Mountain and the tuff of Buck Spring by 
Maldonado and Hausback (1990). Age equivalent to unit Tos in the eastern part of map area, which is mostly sediment, but includes many of the same tuffs. Maximum exposed thickness of at least $600 \mathrm{~m}$

Tos Rocks of Pavits Spring (Miocene) - A thick sequence of mostly tuffaceous sedimentary rocks: arkoses, shales, freshwater limestones, marls, and lesser tuffs; laterally transitional into Tsm, in which the tuffs dominate. Typically a light ochre color on the surface; commonly black in unoxidized samples obtained by drilling on the north side of Bare Mountain. Locally, in the sector graben on northeastern Bare Mountain, may include small exposures of the Lithic Ridge Tuff (T/t) near the top, that are too small to map separately. Maximum exposed thickness of at least $200 \mathrm{~m}$

Tog Older Fluvial conglomerates (Miocene and Oligocene) - Roundstone cobble conglomerates, moderately consolidated with red lateritic matrix in the lower part of map unit (Oligocene Titus Canyon Formation) and green dacitic tuffaceous sandstone matrix in the upper part (the early Miocene "green" conglomerate). Cobbles consist of quartzites and lesser carbonates and argillites, with rare rhyolite lava cobbles found only in the upper part. Maximum exposed thickness of at least $200 \mathrm{~m}$

TKi? Gabbro dikes (Oligocene or Mesozoic?) -- Dark green hornblende gabbro dikes that resemble dikes just south of map area that have been dated at 26.1 Ma and 16.6 Ma (K/Ar, hornblende and biotite, respectively; Monsen and others, 1992). These coarse-grained dikes may be older than Oligocene as the disagreement in ages indicates that the younger age at least is a cooling age. The dikes evidently are younger than the nearby Cretaceous granite, which has acquired a weak metamorphic foliation that is absent in these dikes, but the dikes may be as old as late Cretaceous.

PRE-CENOZOIC BEDROCK 
Kfi Granite (Cretaceous) - Weakly foliated, very pale orange to pale-yellowish-orange, medium-grained, equigranular granitic rock. Contains roughly $50 \%$ quartz, $30 \%$ orthoclase, and $15 \%$ plagioclase, as well as muscovite and oxides, which appear to be alteration products. Dated by U/Pb (zircon) at $98+/-27 \mathrm{Ma}$ (Monsen and others, 1992)

PzPC Pre-Cenozoic sedimentary rocks, undivided (Paleozoic and late Proteroic) - A very thick sequence of mostly miogeoclinal sedimentary rocks including limestones, dolomites, quartzites, and argillites. Locally metamorphosed. Mapped as a collective unit only on the cross sections. Thickness before Mesozoic compression has been estimated at $\sim 11 \mathrm{~km}$

MDe Eleana Formation (Mississippian and Late Devonian?) -- A thick sequence of clastic rocks consisting predominantly of argillite and cherty argillite. Two exposures of this unit, in two different fault blocks in northern Bare Mountain, are separated by the Meiklejohn Thrust and are lithologically distinct, suggesting that they were deposited in settings that were far apart before thrust faulting (Trexler and others, 1996). The western fault block, in the upper plate of the thrust, consists of thinly bedded chert-lithic sandstone, bedded chert, siltstone, and mudstone. The eastern, parautochthonous section consists of a coarse debris flow conglomerate, at the base, overlain by dolomitic siltstone, bedded chert, argillite, and cherty wackestone and mudstone (Trexler and others, 1996)

Df Fluorspar Canyon Formation (Devonian) - Layered light- to dark-gray, fine- to mediumgrained dolomite and limy dolomite containing limestone and quartzite beds in some intervals. Consists of four subunits which, from the top down, have the following distinctive features: (1) interbeds as much as $2 \mathrm{~m}$ thick of medium- to light-brown weathering quartzite, (2) interbeds containing abundant Amphipora, (3) sparse layers of pebble conglomerate, and (4) sparse to moderately abundant light-brown chert nodules. Grades downward into Lone Mountain Dolomite; lower contact is indistinct. Exposed (incomplete) thickness of about $250 \mathrm{~m}$ 
SI Lone Mountain Dolomite (Silurian) - Very light gray, craggy dolomite containing a distinct medium-gray interval near middle of unit. Dolomite is fine- to medium-grained, indistinctly bedded, and commonly brecciated; sparsely fossiliferous with common poorly preserved crinoid debris. Basal contact is gradational and is distinguished from a distance by a distinct downward darkening into the underlying Roberts Mountain Formation. Total thickness is about $490 \mathrm{~m}$

Sr Roberts Mountains Formation (Silurian) - Slope-forming, light-brownish-gray to medium-gray dolomite and limestone containing interbedded silty and sandy dolomite and sparse beds of dolomite-pebble conglomerate. Thinly to thickly bedded, commonly flaggy. Silicified brachiopods and corals are present throughout the unit. Thickness is about 200 m

Oes Ely Springs Dolomite (Ordovician) - Ledge-forming, medium- to dark-gray dolomite and limy dolomite containing abundant dark-gray chert layers and nodules 5 to $20 \mathrm{~cm}$ thick. Basal contact is marked by an abrupt gradation from dark-gray dolomite to the reddish Eureka quartzite. Thickness of about $125 \mathrm{~m}$

Oe Eureka Quartzite (Ordovician) -- Ledge-forming, light-gray to pale-red quartzite and sandstone. Fine-grained, well-sorted, medium- to thick-bedded, containing thin intervals of limy sandstone near the top and base. Basal contact is placed at the downward transition to limestone. Thickness of about $110 \mathrm{~m}$

Oav Antelope Valley Formation (Ordovician) - Ledge- to cliff-forming unit of medium-gray, predominantly nodular, finely to coarsely crystalline limestone and silty limestone, massive to laminated and platy-splitting rock. Pale-orange-weathering silty partings are common in lower and upper parts of unit. Basal contact is abrupt transition to siltstone of Ninemile Formation. Estimated thickness of about $200 \mathrm{~m}$

On Ninemile Formation (Ordovician) - Slope-forming, light- to moderate-brown siltstone and olive-black to dark-medium-gray silty limestone or dolomite. Irregular thin platy layers of 
siltstone alternate with nodular interbeds of silty carbonate rocks. Basal contact is an abrupt transition to pure carbonate of the Goodwin Limestone. Estimated thickness of 85 m

Og Goodwin Limestone (Ordovician) -- Ledge-forming, medium- to dark-gray limestone and lesser silty limestone. Contains pale orange silty laminae and partings, and brownweathering chert lenses. Basal contact is placed at the top of the ledge-forming dolomite of the Nopah Formation. Estimated thickness of $135 \mathrm{~m}$

Cnsh Nopah Formation, undivided (Cambrian) -- Cliff-forming light- and medium-gray, saccharoidal dolomite and much lesser shale, subdivided into the Smoky, Halfpint, and Dunderberg Shale Members:

Cns Smoky Member -- Cliff-forming, very light-gray to medium-gray dolomite in indistinct medium-to-thick beds. Upper part is alternating dark- to medium-gray dolomite containing sparse light-gray beds. Lowermost $70 \mathrm{~m}$ is white to very light gray dolomite. Estimated thickness of $305 \mathrm{~m}$

Cnh Halfpint Member -- Predominantly medium- to dark-gray, thin- to thick-bedded, finely to coarsely crystalline dolomite locally containing abundant black chert nodules and layers, bedding generally indistinct. Estimated thickness of $185 \mathrm{~m}$

Cnd Dunderberg Shale Member -- Greenish-brown, fissile shale containing subordinate medium-gray to pale-brown thinly-bedded limestone. Thickness of $30 \mathrm{~m}$

$\mathrm{Cb} \quad$ Bonanza King Formation, undivided (Cambrian) -- Divided into:

Cbbu Banded Mountain Member, Upper part -- Cliff-forming, finely to medium crystalline, thickly bedded light- to dark-gray dolomite. From a distance, appears as three color bands of approximately equal thickness and that, from top to bottom, are medium gray, very light gray, and dark gray. Thickness of about $180 \mathrm{~m}$

Cbbl Banded Mountain Member, Lower part -- Cliff-forming dolomite and limestone, distinctively striped in alternating light- to dark-gray bands ranging from 0.5 to $6 \mathrm{~m}$ thick. 
Basal contact is mapped at the top of a silty carbonate interval that appears pale orange from a distance. Thickness of about $395 \mathrm{~m}$

Cbp Papoose Lake Member -- Cliff-forming, white to dark-gray dolomite and limestone intercalated with sparse but distinctive yellowish-orange silty and sandy intervals, which at concentrated at the top and base. Estimated thickness is $580 \mathrm{~m}$

Cc Carrara Formation, undivided (Cambrian) -- A heterogeneous unit of slate, phyllite, or schist and fine-grained micaceous quartzite; contains prominent intervals of limestone and silty limestone. Oncoids are common in the limestone beds whereas trilobite fossil hash is common in the pelitic rocks. Divided into:

Ccu Upper part -- Intercalated thin- to medium-bedded, dark-greenish-gray phyllite or schist, micaceous quartzite, and medium-dark-gray limestone. The pelitic rocks are typically dark greenish brown and increase in abundance downsection, whereas the limestone beds are dark greenish gray. Thickness of $200 \mathrm{~m}$

Ccm Middle part -- Cliff-forming, thickly-bedded, dark-gray limestone, Girvenella characteristically are present. Thickness about $60 \mathrm{~m}$

Ccl Lower part -- Similar to upper part of formation. Thickness about $90 \mathrm{~m}$

Cz Zabriskie Quartzite (Cambrian) -- Cliff-forming unit of pale-red to dusky-red, fine- to medium-grained orthoquartzite, thick-bedded and commonly cross-stratified. Scolithus is common in the lower part. Thickness of about $350 \mathrm{~m}$

CZw Wood Canyon Formation (Cambrian and Late Proterozoic) - Mostly slope-forming sequence of siltstones and lesser quartzites with distinctive thin orange dolomite marker beds in the upper and lower parts of formation. Divided into:

Cwu Upper Member (Cambrian) -- Steep-slope-forming sequence of interbedded quartzite and siltstone with thin orange, oolitic dolomite beds in the lower part. Basal contact is the base of the upper dolomite beds. Thickness about $260 \mathrm{~m}$

Zwl Lower member: (Late Proterozoic) -- 
Zwld Unit D (Late Proterozoic) -- Thickly-bedded, brownish-black to moderate-brown, very fine grained micaceous siltstone and quartzite containing sparse interbeds of lightgreen siltstone. Thickness about $50 \mathrm{~m}$

ZwIc Unit C (Late Proterozoic) -- Thin- to medium interbeds of greenish-gray, very finegrained micaceous siltstone and quartzite, capped by $25 \mathrm{~m}$ thick pale-orange dolomite and limestone. Thickness about $80 \mathrm{~m}$

Zwlb Unit B (Late Proterozoic) -- Thin to medium interbeds of greenish-gray, very finegrained micaceous quartzite and siltstone, capped by $20 \mathrm{~m}$ thick pale-orange medium- to thick-bedded dolomite and limestone. Thickness about $110 \mathrm{~m}$

Zwla Unit A (Late Proterozoic) - Thin- to medium interbeds of greenish-gray, very finegrained micaceous quartzite and siltstone, capped by about $10 \mathrm{~m}$ thick pale-orange dolomite and limestone. Basal contact is gradational and is defined as horizon at which quartzite becomes the dominant rock type. Thickness about $100 \mathrm{~m}$

Zse Stirling Quartzite, E member (Late Proterozoic) -- White to pale-yellowish-brown, medium- to thick-bedded, fine-grained orthoquartzite, commonly laminated and crosslaminated. Moderate ridge-forming unit. Maximum exposed thickness of about $50 \mathrm{~m}$

\section{REFERENCES CITED:}

Byers, F. M., Jr., Carr, W. J., and Orkild, P. P., 1989, Volcanic centers of southwestern Nevada: Evolution of understanding, 1960-1988: Journal of Geophysical Research, v. 94, no. B5, p. 5908-5924.

Byers, F. M., Jr., Carr, W. J., Orkild, P. P., Quinlivan, W. D., and Sargent, K. A., 1976, Volcanic suites and related cauldrons of Timber Mountain-Oasis Valley caldera complex, southern Nevada: U. S. Geological Survey Professional Paper 919, 70 p.

Christiansen, R. L., and Lipman, P.W., 1965, Geologic map of the Topopah Spring NW quadrangle, Nye County, Nevada: U. S. Geological Survey Map GQ-444, scale 1:24,000. 
Connors, K. I., Weiss, S. I., and Noble, D. C., 1998, Geologic map of the northeastern Bullfrog Hills and vicinity, southern Nye County, Nevada: Nevada Bureau of Mines and Geology Map 112 , scale $1: 24,000$.

Crittenden, M. D., Jr., Coney, P. J., and Davis, G. H., eds., 1980, Cordilleran metamorphic core complexes: Geological Society of America Memoir 153, $490 \mathrm{p}$.

Crowe, B. M., Perry, F., Geissman, J., McFadden, L., Wells, S., Murrell, M., Poths, J., Valentine, G. A., Bowker, L., and Finnegan, 1995, Status of volcanism studies for the Yucca Mountain Site Characterization Project: Los Alamos National Laboratories Report LA-12908-MS, 363 pp. Eng, Tony, Boden, D. R., Reischmann, M. R., and Biggs, J. O., 1996, Geology and mineralization of the Bullfrog Mine and vicinity, Nye County, Nevada: in Coyner, A. R., and Fahey, P. L., eds., Geology and Ore Deposits of the American Cordillera: Geological Society of Nevada Symposium proceedings, Reno, Nevada, p. 353-402.

Fleck, R. J., Turrin, B. D., Sawyer, D. A., Warren, R. G., Champion, D. E., Hudson, M. R., and Minor, S. A., 1996, Age and character of basaltic rocks of the Yucca Mountain region, southern Nevada: Journal of Geophysical Research, v. 101, p. 8205-8227.

Fridrich, C. J., 1998 and in press, Tectonic evolution of the Crater Flat basin, Yucca Mountain region, Nevada: published as U. S. Geological Survey Open-File Report 98-33, 43 p., and in press in, Wright, L. A., and Troxel, B. W., eds., Cenozoic basins of the Death Valley region, California and Nevada, Geological Society of America Special Paper 333, p. 169-195.

Fridrich, C. J., Minor, S. A., and Mankinen, E. A., 1999, Geologic evaluation of the Oasis Valley basin, Nye County, Nevada: USGS OFR 99-xxx-A

Fridrich, C. J., Whitney, J. W., Hudson, M. R., and Crowe, B. M., 1998 and in press, Space-time patterns of late Cenozoic extension, vertical axis rotation, and volcanism in the Crater Flat basin, southwest Nevada: published as U. S. Geological Survey Open-File Report 98-33, 31 
p., and in press in, Wright, L. A., and Troxel, B. W., eds., Cenozoic basins of the Death Valley region, California and Nevada, Geological Society of America Special Paper 333, p. 169-195. Grauch, V. J. S., Sawyer, D. A., Fridrich, C. J., and Hudson, M. R., 1997, Geophysical interpretations west of and within the northwestern part of the Nevada Test Site: U. S. Geological Survey Open-File Report 97-476, 45 p. written comm., 1999, Geophysical framework of the southwestern Nevada volcanic field and hydrogeologic implications: to be a USGS Professional Paper.

Hamilton, W. B., 1989, Detachment faulting in the Death Valley region, California and Nevada: in, Carr, M. D., and Yount, J. C., eds., Geologic and hydrologic investigations of a potential nuclear waste disposal site at Yucca Mountain, southern Nevada: U. S. Geological Survey Bulletin 1790, p. 51-86.

Hildenbrand, T., Langenheim, V. E., Mankinen, E. A., McKee, E. H., and Jachens, R. C., 1999. Inversion of gravity data to define the pre-Tertiary surface of the Pahute Mesa-Oasis Valley region, Nye County, Nevada: U. S. Geological Survey Open-File Report 99-xxx.

Hoisch, T. D., Heizler, M. T., and Zartman, R. E., 1997, Timing of detachment faulting in the Bullfrog Hills and Bare Mountain area, southwest Nevada: Inferences from ${ }^{40} \mathrm{Ar} /{ }^{39} \mathrm{Ar}, \mathrm{KJAr}$, U/Pb, and fission track thermochronology: Journal of Geophysical Research, v. 102, no. B2, p. 2815-2833.

Hudson, M. R., Sawyer, D. A., and Warren R. G., 1994, Paleomagnetism and rotation constraints for the middle Miocene southwestern Nevada volcanic field: Tectonics, v. 13, p. 258-277.

Le Bas, M. J., Maitre, R. W., Streckheisen, A., and Zannetin, B., 1986, A chemical classification of volcanic rocks based on the total alkali-silica diagram, Journal of Petrology, v. 27, p. 745-750. Lipman, P. W., Quinlivan, W. D., Carr, W. J., and Anderson, R. E., 1966, Geologic map of the Thirsty Canyon SE quadrangle, Nye County, Nevada: U. S. Geological Survey Map GQ-489, scale $1: 24,000$. 
Maldonado, F. and Hausback, B. P., 1990, Geologic map of the northeast quarter of the Bullfrog 15-minute quadrangle, Nye County, Nevada: U. S. Geological Survey Map 1-2049, scale: $1: 24,000$.

Mankinen, E. A., Hildenbrand, T. G., Dixon, G. L., McKee, E. H., Fridrich, C. J., and Laczniak, R. J., 1999, Gravity and magnetic study of the Pahute Mesa and Oasis Valley region, Nye County, Nevada: U. S. Geological Survey Open-File Report 99-xxx.

Minor, S. A., Orkild, P. P., Sargent, K. A., Warren, R. G., Sawyer, D. A., and Workman, J. B., 1997, Digital Geologic map of the Springdale quadrangle, Nye County, Nevada: U. S. Geological Survey Open-File Report 98-623, scale 1:24,000.

Minor, S. A., Orkild, P. P., Swadley, W C, Warren, R. G., and Workman, J. B., 1998, Preliminary Digital Geologic map of the Thirsty Canyon NW quadrangle, Nye County, Nevada: U. S. Geological Survey Open-File Report 97-93, scale 1:24,000.

Minor, S. A., Sawyer, D. A., Wahl, R. R., Frizzell, V. A., Jr., Schilling, S. P., Warren, R. G., Orkild, P. P., Coe, J. A., Hudson, M. R., Fleck, R. J., Lanphere, M. A., Swadley, W C, and Cole, J. C., 1993, Preliminary geologic map of the Pahute Mesa 30' x 60' Quadrangle, Nevada: U. S. Geological Survey Open-File Report 93-299, scale 1:100,000.

Monsen, S. A., Carr, M. D., Rehies, M. C., and Orkild, P. P., 1992, Geologic map of Bare Mountain, Nye County, Nevada: U. S. Geological Survey Map 1-2201, scale 1:24,000. Noble, D. C., Weiss, S. I., and McKee, E. H., 1991, Magnatic and hydrothermal activity, caldera geology, and regional extension in the western part of the southwestern Nevada volcanic field: in, Raines, G. L., Lisle, R. E., Schafer, R. W., and Wilkinson, W. H., eds., Geology and Ore Deposits of the Great Basin, Geological Society of Nevada, Reno, Nevada, p. 913-934. O'Connor, J. T., Anderson, R. E., and Lipman, P. W., 1966, Geologic map of the Thirsty Canyon quadrangle, Nye County, Nevada: U. S. Geological Survey Map GQ-524, scale 1:24,000. 
Reynolds, M. W., 1961, Stratigraphy and structural geology of the Titus and Titanothere Canyons area, Death Valley, California: Unpub. Ph.D. dissertation, University of California, Berkeley, $310 \mathrm{p}$.

Sargent, K. A. and Orkild, P. P., 1976, Preliminary geologic map of the Springdale NW quadrangle, Nye County, Nevada: U. S. Geological Survey Map MF-751, scale 1:24,000.

Sawyer, D. A., Fleck, R. J., Lanphere, M. A., Warren, R. G., Broxton, D. E., and Hudson, M. R., 1994, Episodic caldera volcanism in the Miocene southwestern Nevada volcanic field: Revised stratigraphic framework, ${ }^{40} \mathrm{Ar} /{ }^{39} \mathrm{Ar}$ geochronology, and implications for magmatism and extension: Geological Society of America, v. 106, no. 10, p. 1304-1318.

Slate, J. L., Berry, M. E., Rowley, P. D., Fridrich, C. J., Williams, V. S., and many others, 1999, Digital Geologic map and data base of the Nevada Test Site and vicinity, Nye, Lincoln, and Clark Counties, Nevada, and Inyo County, California: U. S. Geological Survey Open-File Report 99-xxx.

Trexler, J. H., Jr., Cole, J. C., and Cashman, P. H., 1996, Middle Devonian-Mississippian stratigraphy on and near the Nevada Test Site: Implications for hydrocarbon potential: American Association of Petroleum Geologists Bulletin, v. 80, No. 11, p. 1736-1762.

USGS, 1996, Seismotectonic framework and characterization of faulting at Yucca Mountain, Nevada (J. W. Whitney, coordinator): U. S. Geological Survey Report to the U. S. Department of Energy, $v 1-4$, variously paginated.

Wahl, R. R., Sawyer, D. A., Minor, S. A., Carr, M. D., Cole, J. C., Swadley, WC, Laczniak, R. J., Warren R. G., Green, K. S., and Engle, C. M., 1997, Digital geologic map of the Nevada Test Site area, Nevada: U. S. Geological Survey Open-File Report 97-140, scale 1:120,000.

Warren, R. G., Sawyer, D. A., Byers, F. M., Jr., and Cole, G. C., 1998, A petrographic/geochemical database and stratigraphic and structural framework for the southwestern Nevada volcanic field: Accessible on the Internet at http://queeg.ngdc.noaa.gov/seg/geochem/swnvf/ 
NOTICE

Page(s) size did not permit electronic reproduction. Information may be purchased by the general public from the National Technical Information Service, U.S. Department of Commerce, Springfield, VA 22161 (Area Code 703-487-4650). DOE and DOE contractors may purchase information by contacting DOE's Office of Scientific and Technical Information, P.O. Box 62, Oak Ridge, TN 37831, Attn: Information Services (Area Code 423-576-8401). 